\title{
Complementary Approach to Teaching and Learning Entrepreneurship in Nigerian Universities: A Conceptual Framework
}

\author{
Ezekiel Jide Fayomi1 $^{1, *}$, Ziska Fields², Kayode Kingsley Arogundade ${ }^{1}$, Hammed Olabode Ojugbele ${ }^{2}$, \\ Folake Ogundipe ${ }^{1}$, Idris Olayiwola Ganiyu ${ }^{2}$ \\ ${ }^{1}$ Department of Business Administration, Faculty of Management Sciences, Ekiti State University, Nigeria
${ }^{2}$ School of Management, Information Technology and Governance, University of KwaZulu-Natal, South Africa
}

Copyright $\bigcirc 2019$ by authors, all rights reserved. Authors agree that this article remains permanently open access under the terms of the Creative Commons Attribution License 4.0 International License

\begin{abstract}
Purpose- The conventional mode of teaching entrepreneurship in most of the Nigerian universities seems to not be sufficiently adequate to increase entrepreneurial action to decrease rates of graduates' unemployment. Design/methodology/ approach- Adopting primary and secondary sources of data, the article examined the influence of teaching and learning methods on perceived desirability for entrepreneurship. A total of 701 questionnaires were administered, of which 664 questionnaires were validly retrieved through combining stratified and systematic sampling techniques. The investigation yielded $94 \%$ response rate from the population groups of lecturers, postgraduate and final year students of three selected universities in Southwest Nigeria. Inferential statistics including Pearson's correlation, t-tests, and chi-square at p-value (0.05) level of significance were employed for the statistical analyses. Findings-The university-level entrepreneurship training demands cognitive and non-cognitive activities as the minimum benchmark for learning entrepreneurship. The operating curriculum predominately remains academics while performance assessments are written examinations which are mark driven. A significant positive correlation was established between the use of more theoretical learning patterns and the mind-sets for remunerative employment, as opposed desirability for entrepreneurship. Research limitations/implication- The content of information in this study limits the results of the research to the studied participants, which also limits the reach of the study to the three universities, where the study was conducted. Originality/ value- The value is a guiding framework that promotes paradigm shift from perspective highly curriculum content-based approach to a more inclusive outcome-based model, that is more of collaboration, partnership and engagement with key stakeholders in entrepreneurial development.
\end{abstract}

Keywords Higher Education, Entrepreneurship, Innovative Teaching, Pedagogy, Unemployment

\section{Introduction}

Nowadays, the trend around entrepreneurship development suggests that the framework for teaching and learning is in the era of education and training $[61,63]$. For inastance, a number of existing studies found a positive impact of education and training framework on entrepreneurial learning outcomes $[9,16,20,40,41,45,46$, 64], a positive correlation is reported between teaching entrepreneurship and the desire to participate in entrepreneurial activities. Recently, [64] found a marked relationship between entrepreneurship education and the chances of becoming practising entrepreneurs. Similarly, other empirical studies have established a significant relationship between entrepreneurial education, self-employment and job creation [44, 49]. This understanding perhaps informs the decision of universities in the United States, Europe, East Asia and Latin America to design and implement creative strategies for the teaching entrepreneurship. Such a precedence, according to [36], is worthy of emulation by other countries of the world. University education in Nigeria is not an exception, and this is the major reason why stakeholders in education industries called for a review of teaching methods with a view to strengthening the existing framework.

According to [5], innovative teaching strategies could always equip students with job skills and experience necessary to operate successfully in the labour market. In the studies conducted by [41, 45, 64], it is affirmed that entrepreneurship is teachable across students' career choices both at formal and informal education settings. 
The roles of educational institutions include curriculum development, training and developing the academic staff [2]. Expectedly, educational institutions like a university could act as a bridge between practitioners, students and lecturers in the context of schools' entrepreneurship programmes [31, 41]. It is instructive to note that entrepreneurs who are educated had advantages in contributing to Gross Domestic Product (GDP) of nations of the world [47]. This article considers the submission of [29] that the universities are fast becoming centres of attention in the world. Accordingly, the context of entrepreneurship education and training is a product of innovations and best practices obtainable in other parts of the world. According to the European Commission's report cited in [18], a guiding framework provided to assist universities around the world is sacrosanct to the pursuing of schools entrepreneurship development programmes.

A framework is aimed at creating an entrepreneurial university through insights, inspiration, advice, and ideas of how schools entrepreneurship education can effectively be administered. According to the European Commission's report, seven cardinal yardsticks are specified as key performance indicators. These indicators include leadership and governance; organisational capacity, people, and incentives; entrepreneurship development in teaching and learning; pathways for entrepreneurs; university-business/external relationship for knowledge exchange; entrepreneurial university as an international institution; and measuring the impact of the entrepreneurial university. Prior to the introduction of entrepreneurship studies in Nigeria, the National Policy on Education emphasised the need for a programme action which promotes activity-based learning, practical exposure and community involvement as part of learning approaches [4]. Understanding the teaching methods fashioned after collaborative efforts could be impacting. It is also believed that such interaction is capable of bridging the gap that exists between the graduates and the skills required in the workplace. Costello as cited in [14] argues that "teaching, learning, and assessment strategies should not only be targeted at creating mindsets but also at imparting specific entrepreneurial skills and competencies for employment generation.” It follows that complementary teaching approaches could stimulate learners' awareness, mindsets, drive, and interests.

The need for a paradigm shift according to [61] is linked to the argument that a learning synergy between entrepreneurs and students can be a strong pedagogy. The chances are higher when training interventions are promoted towards providing additional skills. Bicaba, Brixiova and Ncube in [10] developed a model of costly firm creation based on skill acquisition and training between adult and young entrepreneurs. The relevance of skill and training framework is stressed as a strategy to drive entrepreneurship education in $21^{\text {st }}$ Century.
Similarly, studies by $[51,53]$ underscored the significance of integrating industrial activities and process into learning the product development. The aim is to bridge the gap that exists between abstract knowledge and industrial skills. Similar study reported in [59] also discussed a team-building synergy between classroom learning and industrial exposure. The merger between the university engineering designed programme and some local industries provide the students with a platform to display the knowledge of abstract. The implication is that the combined effort achievable through entrepreneurship education and training designs is capable of stimulating intellectual property and innovation among entrepreneurial learners. Similarly, the study as reported in [14] affirmed real learning model underpinning by experience and reflections as capable of deepening knowledge of theories or concepts students acquire from the classroom.

The idea of the complementary approach is aimed at providing learners with a platform that actively engages them with activity-based learning in addition to what they are taught in the school. Teaching and learning entrepreneurship requires different approaches because entrepreneurial students learn differently and they have different learning moments [23, 42]. The students exhibit a higher preference for experiential interventions through active, practical, concrete, visual and reflective teaching. The focus of the article is to determine the outlook of framework for graduates' training, employment and job creation. This is in line with the submission that blending activity-based learning with the long-established traditional lecturing method could provide learners with stronger competence and experience [5, 13]. A recent knowledge also suggests that the process of how entrepreneurship training programme is conducted has a potential influence on the quality of learners that could be produced [38].

A cursory review of these studies indicates that research in the area of delivery framework remains a 'gap' in the entrepreneurial literature. This is in agreement with the studies conducted by [6,42], which describe an empirical investigation into what and how entrepreneurship education pedagogies are designed, as a possible area for further research. Studies that investigate entrepreneurial intention among education groups about the influence of adopted teaching and learning strategies in the universities in South-West Nigeria are scanty. To mitigate the difficulties in securing organisational employment, the Federal Government of Nigeria, through the National University Commission (NUC), introduced the teaching and learning of entrepreneurship into the curriculum of Nigerian universities in 1987 with the aim of providing self-employment training to undergraduate and postgraduate students [39]. The objective of such training is to serve as a motivation for manpower development, self-employment and economic development of the nation. Entrepreneurship has been identified as key to the political 
and economic development of many developed countries of the world. The economies of many developed nations are driven by entrepreneurs. The advantages of this trend range from springing up of small and medium scale businesses, creation of jobs as well as wealth for the nation [7, 49].

Despite the introduction of entrepreneurship into university education curricula, the rate of graduates' unemployment is on the increase. Today, the aspirations of many undergraduates remain how to secure remunerative employment with government and few available private sectors. This is attributed to academic programmes tailored towards producing graduates with a desire for paid employment [60]. Most university and college graduates lack basic entrepreneurial skills coupled with a dearth of exposure to industries. Other findings in the literature indicate lack of consensus on the issues bordering on the adoption and implementation of entrepreneurship education programmes [45, 61]. The debates remain unresolved how entrepreneurship is teachable or learnable, the choice of audience, curriculum content, teaching, learning, assessment, and evaluation framework. The broad objective of this article, therefore, is to deepen the teaching and learning entrepreneurship in the Nigerian universities. The specific objectives are:

- To determine university-level entrepreneurship training and methods along groups demographic profile.

- To understand how participating groups perceived realistic activities and the influence on intentions to engage in entrepreneurial activities.

- To determine the complementary approaches to learning entrepreneurship in the universities.

\section{Literature Review}

The term entrepreneurship is conceptualised differently by different scholars. On one hand, some schools of thought view entrepreneurship as a process of developing entrepreneurial mindsets $[2,27]$. It is a process of initiating business ventures, organising profitable business transactions and taking calculated risks based on previously acquired experience [7]. This also includes acquiring prerequisite skills, competencies and experience to advance the world of business [63]. This definition aligns with the perspectives in [9], which refers to entrepreneurship as "acquiring business skills for employment to function effectively in the turbulent business environment, to improve the individual economic status and the nation at large”.

Debates abound on whether or not entrepreneurship can be taught as an academic discipline or whether the individual entrepreneurial behaviour is natural or inborn. There are robust arguments in the literature in support of entrepreneurship as being teachable and learnable [48]. Recent knowledge in the literature, for instance, [51, 63], confirm a marked significant relationship between the appropriate mix of teaching and learning strategies and entrepreneurial skills required by students. Entrepreneurship can be taught, and students can be equipped with skills right from the school. Other schools of thought acknowledged social factors, genetic and family background, as capable of influencing entrepreneurial attitude [32, 36]. The development of entrepreneurial knowledge and skills according to [32] also include natural-born entrepreneurs, socially prepared entrepreneurs, and educationally prepared entrepreneurs. This article does not exclude other literature which explains the aspects of entrepreneurship that are teachable and non-teachable [6]. It is further asserted that the teaching and learning entrepreneurship is both an art and a science. While the science relates to the aspects that are teachable and involved the acquisition of functional skills for business start-up, the art components deal with creativity, which is not expressly teachable.

As such, the focus of entrepreneurial contents and training relates to scientific approaches in most higher education institutions. Similarly, the study cited in [6] established that entrepreneurship education is better ignited through the artistic, creative and perceptual framework. Lee and Wong unanimously support the need for a shift from a scientific approach to more artistic and creative learning methods. Similarly, a contemporary study contained in [16] explains the requirement for developing an effective model to manage teachable skills. It is noted that the relationship between students' learning needs and adopted learning framework is a critical factor in teaching and learning entrepreneurship. The framework includes identifying what constitutes the appropriate match between the students' learning needs and teaching techniques. The concern in this article is linked to [6] finding, which narrates that effective management of teachable entrepreneurial skills is substantially influenced by the framework for teaching and learning. The framework includes negotiation skills, leadership, technological innovation and creative thinking.

\section{Teaching and Learning Pedagogy}

This article takes cognisance of the fact that formulating proper reasoning will only occur when appropriate learning strategies are in place [25, 63]. The European Union report cited in [62] also concurs with the fact that what students are taught and how they are taught, have implications on how best they learn. For instance, at British University, an experiment was conducted on 114 students who enrolled for different entrepreneurship courses based on theoretical and practical learning orientation [51]. The students with higher self-efficacy and theoretical lecturing orientation had higher prevention disposition toward entrepreneurial behaviour. The other group with higher self-efficacy seemed to have developed his promotion orientation for 
entrepreneurship. The implication is that individual entrepreneurial intention is a product of the relationship that exists between self-efficacy, self-regulation and entrepreneurial orientation in the context of adopted teaching and learning framework. From the results of the research, students who learnt through practical training performed better than those in the theoretical class [32]. The first question that comes to mind is what is it to learn to become entrepreneurs. The simple answer is rested on the adopted method and how these align with the behavioural theory, social learning, situated learning and existential learning theories [46]. These are the four critical pivots on which designing entrepreneurship education programmes for a sustainable entrepreneurial mindsets development rotates [62]. Presentations in table 1 , provide the key components (what, where, who and how) entrepreneurial training programmes are approachable towards maximising the participation of entrepreneurial learning audience.

From table 1, it is provided that four components form the basis for deciding the framework for teaching and learning entrepreneurship. According to the world economic forum report, the question of what should be taught, who should teach, where to teach and how to teach entrepreneurship, has remained the subject matter of debate in the entrepreneurial research. The key determining factors of how a successful entrepreneurship education programmes are likely to run more effectively, are directly related to what is taught (course contents), who teaches (audiences), how (pedagogy) and where (study environment). With particular reference to how to teach entrepreneurial students, [62] narrate interactive learning centred pedagogies, the use of multi-disciplinary programs and projects, case studies, games, simulations, business plans and competitions as the framework. The European Union report also specifies the extensive use of visuals, digital tools, and multimedia, learning by doing/hands-on activities, experiential learning/laboratory (trial and error), projects, internships with start-ups, mentoring and interactions with entrepreneurs, as teaching and learning model in the $21^{\text {st }}$ Century. Similarly, what to teach spells out the outlook of the curriculum contents, which include building opportunity identification, self-confidence, self-efficacy and leadership, creativity, business skills, financial skills, business growth skills and negotiating skills.

Table 1. Components of entrepreneurship pedagogy global practices

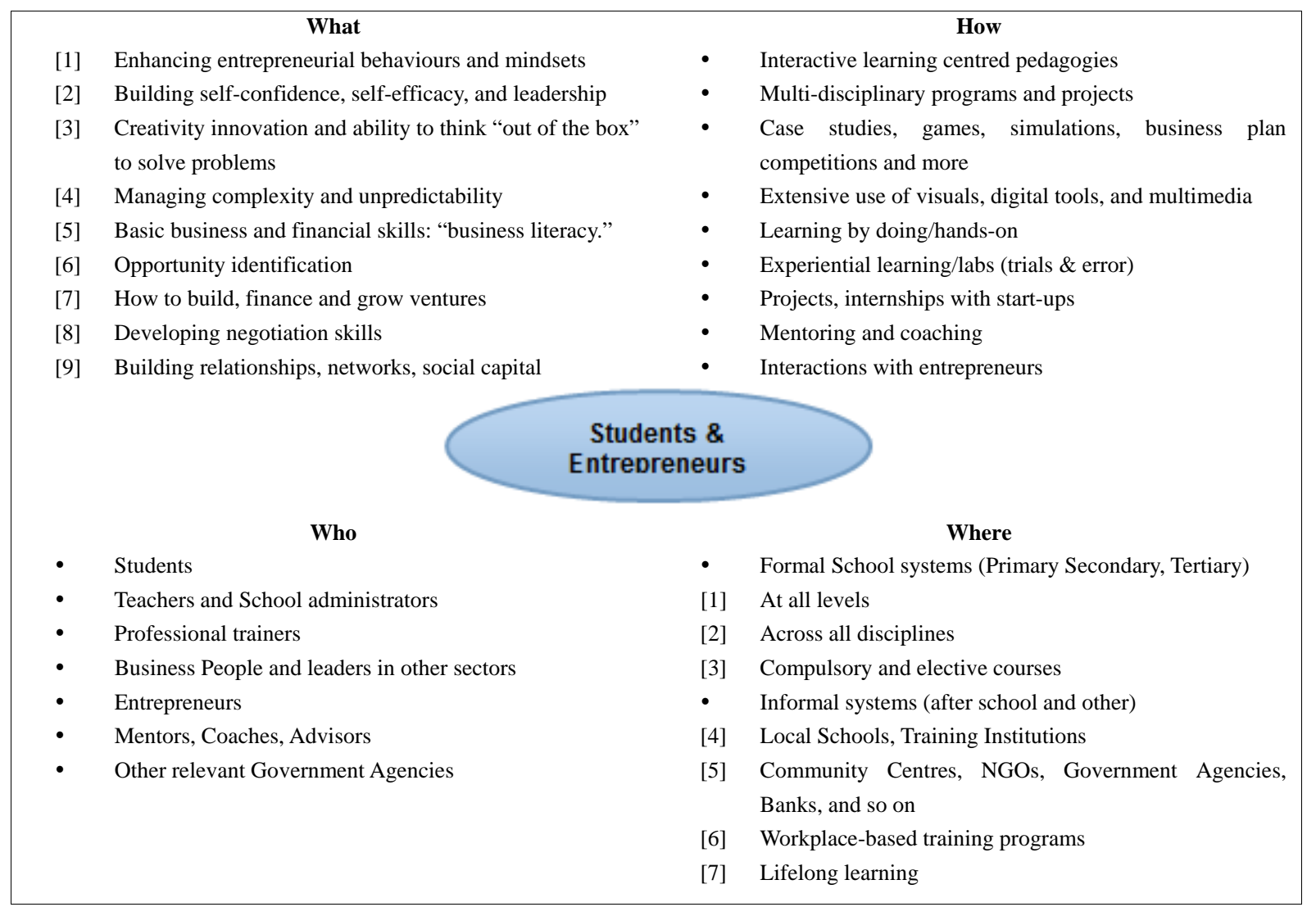

Source: Report of World Economic Forum cited in [62] 


\subsection{Review of Entrepreneurship Education in Teaching Context}

Teaching is closely linked to learning, thus difficult to define, yet it has been defined in several dictionaries and by scholars as 'the imparting of knowledge or skill; the giving of instruction'. Similarly, 'instruction' in this context is usually defined as 'furnishing others with knowledge and information, especially by a systematic method' [63]. It is only in the last decade that these traditional definitions have been challenged and the role of a teacher somewhat redefined due to new beliefs about how learning occurs, and the optimum conditions under which it takes place. Teaching includes activities carried on both inside and beyond the classroom, such as leading a discussion of solutions to problems, probing student answers, creating and maintaining an orderly and supportive environment for learning, reviewing materials, as well as listening to, evaluating and assessing student performance. It also includes broad cultural competence and relational sensitivity, communication skills, and the combination of rigour and imagination fundamental to effective practice [9]. Similarly, a study conducted by [5] on teaching models among technical and vocational education teachers in Nigeria, has found and reported that entrepreneurship teachers could as well display a high level of business skills and employ more of problem-based, content-based, student-centered, demonstration and computer-based methods to engage their students, as significant predictors of learning entrepreneurship skills in the schools.

These methods expose learners to a demonstration of skills in addition to class engagement through the classic model. This position is also related to what [33] described as the "role of inquiry teaching" in the execution of schools" entrepreneurial programmes. According to the aforementioned, approaches such as problem-based could expose learners to experiential learning atmosphere which promotes problems observation, inquisitiveness to ask questions and explanations relevant to the solution. Teaching methods are designed techniques for motivating and inspiring students towards entrepreneurial career or mindsets [63]. The concept of teaching methods in entrepreneurship is well defined by scholars in the literature. According to [6], the traditional lecturing methods are classified as a case study, group discussion, individual presentation, report writing, group projects, lectures, guest speakers, seminars, action learning, web-based/e-learning, videos and simulations, and games. A similar study cited in [1] established that the students' academic achievement is mostly the reflection of the quality of teaching method used. Several researchers allude to the possible influence of chosen instructional strategies on attitudinal change of entrepreneurial learners [23, 42].

\subsection{Review of Entrepreneurship Education in Learning Context}

The proper understanding of how learning occurs is critical towards creating entrepreneurial orientation for future development. Learning is the act of acquiring new, or modifying and reinforcing, existing knowledge, behaviours, skills, values, or preferences and may involve synthesising different types of information. Progress over time tends to follow a learning curve. It does not happen all at once, but builds upon and is shaped by previous knowledge. Learning is conceived in this article as a process, rather than a collection of factual and procedural knowledge. This is recognising the fact that most definitions of learning refer to learning as a change in behaviour that is due to experience. In other words, learning is defined as an effect of experience on behaviour. As a result, entrepreneurial graduates would be a product of experiential learning any student could gain from the internship, simulation, and others which could be put together in a conceptual model for teaching entrepreneurship. A study as cited in [23] justifies Kolb’s 1984 experiential learning cycle which provides a balance of complementary activities suitable for different learning techniques. Kolbs Learning Theory affirms that effective learning is better ignited through experiential activities categorised as forming an abstract concept, observation and reflection, testing in a new situation and concrete experience.

Similarly, Kolb's 1984 cited in [35] explains experiential style as a learning process by which the concepts and principles which influence individual behaviour in a particular situation is derivable. Similarly, [23] also argued that both teachers and learners strongly favour experiential teaching methods. In another development, the authorities in [3] also explored the use of Kolb's Theory in a similar study conducted in University Putra Malaysia to determine the significance of student learning styles on the preferred teaching methods. Basing his findings on the grounded theory approach, [23] also concludes that experiential pedagogical interventions are required for effective entrepreneurship education. Earlier, [1] described those factors to be considered while determining the effective design of teaching and learning framework as: (i.) that selected teaching and learning methods should be right for the learners (ii.) the method should also be right for the lecturers (iii.) the method must be relevant to the objective of the subject matter; and (iv.) the chosen method must be right within the available resources.

\section{The Theoretical Framework}

The findings in this article is perhaps among few studies in entrepreneurial research that engages teaching strategies in the context of learning objective, learning process and learning outcomes. This article is aimed at examining aspects of cognitive and non-cognitive psychology from a theoretical point of view. The background will then be used to develop a framework specifically to understand teaching-learning processes and outcomes. Such 
framework will be useful in a variety of ways to education and discipline areas. However, this research is positioned to advance current knowledge in the context of university-level teaching and learning entrepreneurship. In the first instance, the Ajzen's 1991 theory of planned behaviour is adopted to explain the objectives of this article. The purpose of adopting this theory is to provide background information regarding how individual entrepreneurial behaviour is developed and what pedagogy framework is most suitable for entrepreneurship education and training. An in-depth understanding of the synergies is proposed to address objective 3 in this article. The justification is related to the utilisation of the tenets, principles, and practices of Theory $\mathrm{U}$, to determine an integrated framework deemed appropriate for teaching and learning entrepreneurship in the selected universities in South-West, Nigeria.

This research is intended to expand the existing theories in entrepreneurial research, Otto Scharmer 1980s Theory U concept, which promotes initiatives for blended strategies, and new thinking in the ever-changing knowledge society. Theory $\mathrm{U}$ establishes the significance of the individual, institutional and environmental factors about human training and development $[31,58]$. Such intervention has the capacity to suspend the regular way of learning in a $U$ formation from the first stage mediated by individual self-efficacy. The conventional practice, where the lecturers come to classes, teach and leave, regards individual learners as passive listeners. Theory $U$ further appears to canvas for letting go the old way of thinking or downloading information to the next stage of co-creating learning activities. The review of the theory will demonstrate the nexus between delivery approaches, perceived desirability and graduate entrepreneurial intention. Such understanding would inform the model idea for conducting university entrepreneurship education and training, as well as the significance to the in-depth understanding of the relationship between the objectives of this article and planned behaviour.

\section{Methodology}

The research design is descriptive premised on the fact that the article is interested in the description of the identified variables in terms of frequencies and averages. A self-administered questionnaire adapted from related studies is used to elicit responses from the respondents based on a six-point Likert scale fundamental to the level of agreement to the statements contained in the questionnaire. Descriptive statistics including means and standard deviations, where applicable are used. Frequencies are represented in tables or graphs. Chi-square goodness-of-fit-test: A univariate test, used on a categorical variable to test whether any of the response options are selected significantly more/less often that the others. One-sample t-test is used to test whether the average value is significantly different from a value of 3.5 (the central score). This is applied to a 6-point Likert scale questions according to (strongly disagree-1, disagree-2, strongly disagree- 3 , slightly agree- 4 , agree- 5 and strongly agree-6). Chi-square test of independence is used on cross-tabulations to see whether a significant relationship exists between the two variables represented in the cross-tabulation. The article also makes use of independent sample t-test (tests for significant differences in average responses between two independent groups). The essence is to provide Fisher's exact test in case the conditions are not met.

At the bivariate level of the analysis involving inferential statistics, Pearson correlation coefficient was used to examine the relationship between two variables while analysis of variance (ANOVA) was used to investigate the difference in means as appropriate. In the summary contained in [54] explain Pearson correlation coefficient as a statistical tool used to measure the direction, strength and significance of bivariate relationship among research variables in a given study. Similarly, the article employed the use of Welch tests of equality of means to determine the central location of the means and compare normality in distributions between variance of the means [22]. The implication is that the Welch test of the mean of equality was conducted to determine Fisher exact results between classical two-sample models with equal variance. Such cross-tabulations allowed this article to determine whether a significant relationship exists between the two variables represented in the cross-tabulation, particularly where the variance obtained from F-statistics of equality of the means shows nearly equal results. Seven hundred and ten (710) copies of the questionnaire are administered on lecturers, final year students and postgraduate students at different faculties at the three universities. The article employs a combination of stratified, systematic and simplified proportional sampling technique by Yamane cited in [28], to select sample size. According to [55], this sample size is representative and justified the required level of confidence and precision. The number of respondents who participated in the findings of this article appears in Figure 1.

The result of the field work yielded 93.52\% response rate using inferential statistics including Pearson's correlation, t-tests, and chi-square with a p-value of 0.05 level of significance. This is done through Statistical Package for Social Science (SPSS) for the statistical analysis of six hundred and sixty four (664) copies of the returned questionnaire. The research is a product of data collected through primary and secondary sources. The three universities selected comprise one federal, one state and one private university. These are Federal University of Technology, Akure, Ekiti State University, Ado-Ekiti and Babcock University respectively. The total number of three hundred and sixteen (316) full-time students at the final year levels and one hundred and thirty (130) postgraduate students and two hundred and fourteen (214) lecturers participated in the study. 


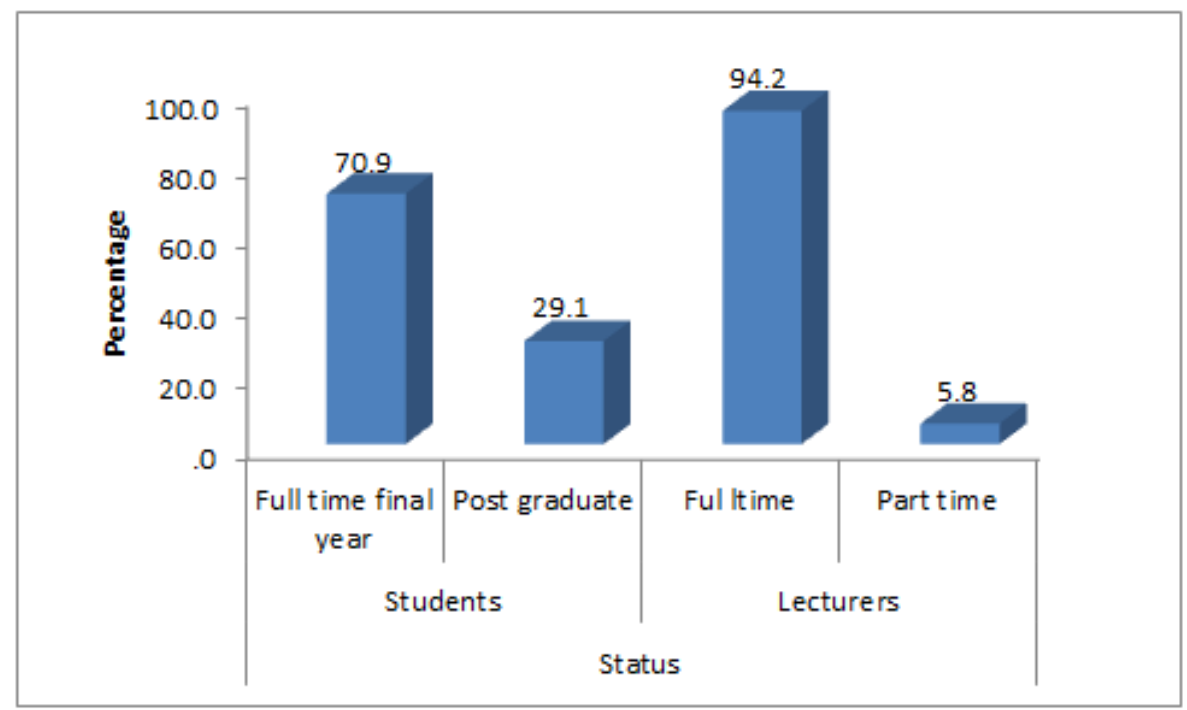

Figure 1. Status of groups/ respondents who participated in the study

\section{Results and Discussions}

The focus of this article is to provide a conceptual model for graduates' entrepreneurial training by investigating some learning pedagogies and the influence on entrepreneurial mindsets. In this article, three research questions are determined in the context of approaches to university-level entrepreneurship training.

- To what extent are students and lecturers deferring on teaching and learning methods effects in the university-level entrepreneurship training?

- To what extent are students and lecturers perceived realistic activities and the perceived desirability for entrepreneurial activities?

- What is the outlook the framework perceived as complementary to the teaching of entrepreneurship?

\subsection{Relationship between Entrepreneurial Training and Individual Intention}

The current practices also indicate that most of what is done in the universities relate to lectures and classwork as depicted in figure 2 :

The presentations in figure 2, provides an array of strategies and subsequent application in conducting learning activities. The data indicate that the use of the traditional face-to-face lecturing method accounts as the most frequently used method of learning in higher education institutions in Nigerian. The non-cognitive related activities such as business networking, mentoring, internships, coaching, self-regulation/practices, and fieldwork are accorded less priority. Relying mostly on traditional lecturing method for entrepreneurship training and development would only result in knowledge of theories because the methods lack the basic initiative for the application [56]. The results of this finding established that level of skills achievable will be marginal, when the model of learning substantially remains formal or traditional lecturing method. Such finding as obtained in this article aligns with similar research conducted under the European university enterprise by Gibeus et al. 2006 cited in [29]. Gibeus et al.'s study compared the performances of the three approaches adopted for entrepreneurship training programmes between formal teaching programme, informal or active enterprise training activities and the control group, who neither had the former or the latter exposure. The result of the investigation showed the higher positive impact on the entrepreneurial intention of the students who learned through the active or non-formal model (seminars, simulation, group project) over the formal or traditional model (lectures and case studies) as well as the other group who were not exposed. Gibeus et al. 2006 concluded that conducting entrepreneurship training through formal or traditional lecturing method did not necessarily lead to the formation of business enterprises. 


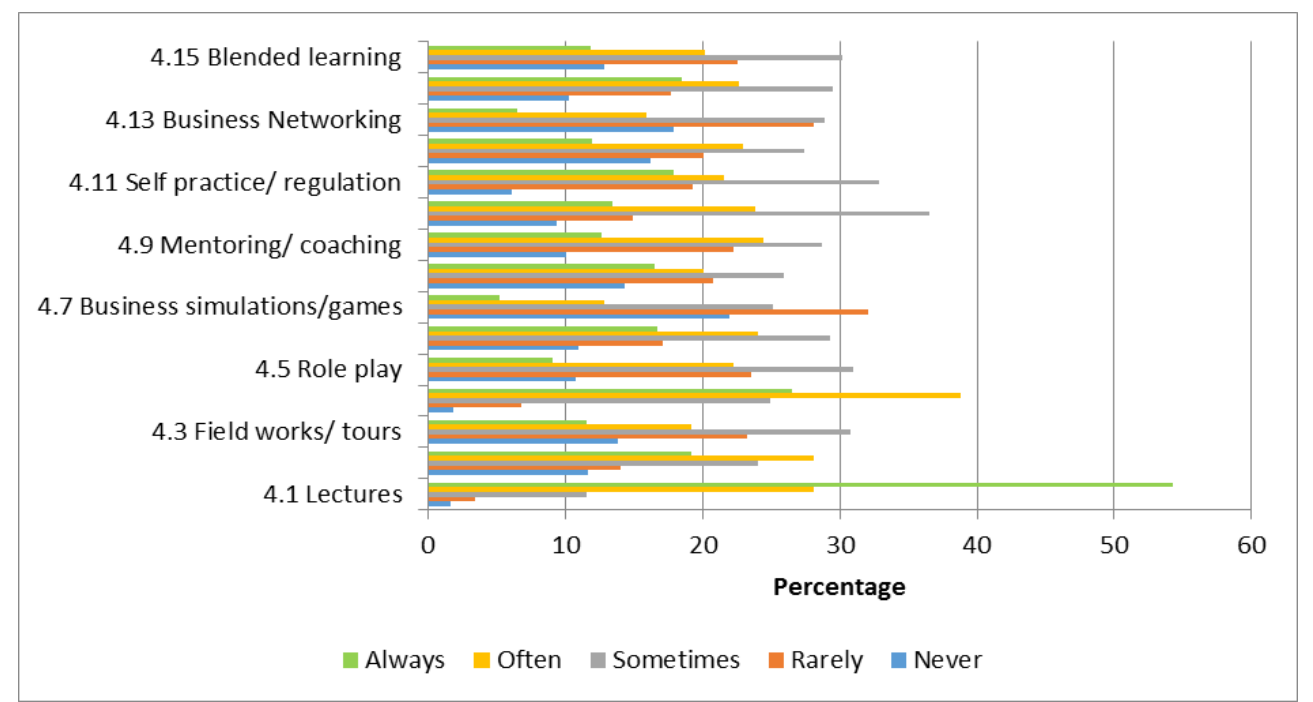

Source: Fieldwork (2015)

Figure 2. Frequency of methods used in University EET

\subsection{Differences in Opinions across Groups of Participants}

The results of the findings in the context of the quantitative data indicate that significant differences exist in the perceptions of the participants according to their groups. For instance, further findings established a significant difference in average agreement scores for the students and lecturers about the use of practical classes. Similarly, the results of past studies have been contradictory. For instance, the study in [15] found that students from such backgrounds like engineering and sciences have higher entrepreneurial tendencies. On the other hand, other scholars like [30, 43] established students from business-related disciplines as having higher entrepreneurial intention. The findings of this article are therefore reported according to differences in perceptions of groups who participated in the research. Table 2 provides the comparison between lecturers and students responses to the methods of learning as well as the significant influence as follow:

Table 2 shows a significant difference in average agreement scores for the students and lecturers about the use of practical classes $(\mathrm{t}(527.199)=-4.723, \mathrm{p}<.0005)$. Lecturers agree more $($ mean $=4.71)$ than students $($ mean $=$ 4.17) that this form of learning is used. Similarly, results obtained from the article revealed that the institutional factors effects on entrepreneurship education development including government regulations, curriculum and educational policies significantly influence learning outcomes. Also, ANOVA was used to determine if there is a significant difference in average scores of methods of teaching and learning entrepreneurship among federal, state and private universities. More importantly, part of the findings of this research established a variation in the views was found from the respondents across the cluster private, state and federal universities as case studies.

The findings agree with the position of [29] that performance variation across faculties or institutions is as a result of quality academic framework guiding the delivery of entrepreneurship training.

The level of disparity in the agreement between population groups as presented in table 2 gave credence to this research in terms of determining the extent of differences across groups of the respondents. For instance, the article determined if there were significant differences among student groups by gender, age and academic status. The independent samples t-test or ANOVA was used to compare the means of more than two categories of a variable and test significant differences across categories. Similarly, to determine exact location of the means and compare normality in distributions, Welch test was conducted between variance in equality of the means [22]. For instance, the idea of student groups by gender was to determine if the issue of gender significantly widens the gender gap as already established by some empirical studies. The results of the analysis are presented as follows: 
Table 2. Comparison of lecturers' and students' rating methods in this study

\begin{tabular}{|c|c|c|c|c|c|}
\hline Teaching methods & Respondents & $\mathbf{N}$ & Mean & $\begin{array}{c}\text { Std. } \\
\text { Deviation }\end{array}$ & $\begin{array}{c}\text { Std. Error } \\
\text { Mean }\end{array}$ \\
\hline \multirow{2}{*}{ Face-to-face teaching } & Students & 442 & 4.70 & 1.437 & 0.068 \\
\hline & Lecturer & 218 & 4.88 & 1.201 & 0.081 \\
\hline \multirow{2}{*}{ Theoretical classes } & Students & 437 & 4.39 & 1.424 & 0.068 \\
\hline & Lecturer & 217 & 4.30 & 1.430 & 0.097 \\
\hline \multirow{2}{*}{ Practical classes } & Students & 438 & 4.17 & 1.577 & 0.075 \\
\hline & Lecturer & 218 & 4.71 & 1.258 & 0.085 \\
\hline \multirow{2}{*}{ More theory than practical work } & Students & 440 & 4.28 & 1.513 & 0.072 \\
\hline & Lecturer & 216 & 4.19 & 1.462 & 0.100 \\
\hline \multirow{2}{*}{$\begin{array}{l}\text { Learning from experienced entrepreneurs and } \\
\text { other stakeholders }\end{array}$} & Students & 440 & 4.15 & 1.486 & 0.071 \\
\hline & Lecturer & 218 & 4.52 & 1.208 & 0.082 \\
\hline \multirow{2}{*}{$\begin{array}{l}\text { Assessment of student self-practice, } \\
\text { regulation \& efficacy, and more }\end{array}$} & Students & 440 & 4.21 & 1.478 & 0.070 \\
\hline & Lecturer & 220 & 4.55 & 1.202 & 0.081 \\
\hline
\end{tabular}

\subsection{Variation across Student Groups by Demographic Profiles}

From the presentation in table 3 , the results indicated that no significant differences across gender were found among the student groups (full-time and post-graduate). For instance, the questions $1 \& 2$ results indicated (4.15, 4.28) $(4.67,4.81)$ male and female agreements respectively. The responses to question 3 , however, showed significant differences between female and male population as (4.69>4.37) (female>male). The implication is that female students seem to agree more than the male students that graduates would prefer to combine government job with the entrepreneurial business venture. The import of these results is that women are more likely to show higher attitude for organisational employment over entrepreneurship than the male population group. Such findings align with recent empirical studies by [19, 57], which have established the fact that women are more likely to be risk-averse in pursuing entrepreneurship than men. For instance, in the United States, [19] establish the fact that women drop off in entrepreneurship career is higher than men. The article further narrates that only about $10 \%$ of business start-up in the US is owned by women population group.

From the presentation in table 3 , the results indicated that no significant differences across gender were found among the student groups (full-time and post-graduate). For instance, the questions $1 \& 2$ results indicated (4.15, 4.28) $(4.67,4.81)$ male and female agreements respectively. The responses to question 3 , however, showed significant differences between female and male population as (4.69>4.37) (female>male). The implication is that female students seem to agree more than the male students that graduates would prefer to combine government job with the entrepreneurial business venture. The import of these results is that women are more likely to show higher attitude for organisational employment over entrepreneurship than the male population group. Such findings align with recent empirical studies by [19, 57], which have established the fact that women are more likely to be risk-averse in pursuing entrepreneurship than men. For instance, in the United States, [19], establish the fact that women drop off in entrepreneurship career is higher than men. The article further narrates that only about $10 \%$ of business start-up in the US, is owned by women population group. 
Table 3. Group statistics comparing student groups by gender

\begin{tabular}{|c|c|c|c|c|c|}
\hline \multicolumn{2}{|c|}{} & $\mathrm{N}$ & Mean & Std. Deviation & Std. Error \\
\hline \multirow{2}{*}{$\begin{array}{c}\text { 1.Prefer government / private job to } \\
\text { entrepreneurship }\end{array}$} & Male & 259 & 4.15 & 1.573 & .098 \\
\cline { 2 - 6 } & Female & 184 & 4.28 & 1.640 & .120 \\
\hline \multirow{2}{*}{$\begin{array}{c}\text { 2. Prefer government / private job first } \\
\text { before moving into entrepreneurship }\end{array}$} & Male & 259 & 4.67 & 1.325 & .082 \\
\hline & Female & 184 & 4.81 & 1.201 & .088 \\
\hline $\begin{array}{c}\text { 3.Prefer combining government / } \\
\text { private job with entrepreneurship }\end{array}$ & Male & 259 & 4.37 & 1.356 & .084 \\
\cline { 2 - 6 } & Female & 184 & 4.69 & 1.146 & .084 \\
\hline
\end{tabular}

A similar development is confirmed in Nigeria by Okafor and Mordi, 2010 cited in [21], that women participation in entrepreneurship is less when compared with the male population. Similarly, the perceptions of the student groups were determined by age along individual preference or intention for entrepreneurship as well as organisational employment. The analysis provides the breakdown of the age profile of the respondents by groups. The presentation shows that a large proportion of the student groups who participated in this article, were young people aged 21-25 years (39.7\%); about $16 \%$ were in the $16-20$ year age group, $24.2 \%$ were aged $26-30$ years, while the rest were above 30 years (19.9\%). This age distribution implies that the students were mature enough to make a correct judgement and appraise their entrepreneurial intentions. A robust test of the equality of mean using the Welch tests in addition to descriptive tests of student groups by age is further explained as follows.

The analysis in table 4 shows that no significant difference was found across age of the student groups, who participated in the findings of this article in the context of objectives 2 and 3, (Welch 4, 145.747) $=.793, \mathrm{p}=.532$ and (Welch $4,142.567)=.590, p=.590$ respectively. The only exception, however, was question 1 (Welch 4, 143.080) $=2.964, \mathrm{p}=.022$, where students age groups between $36+>16-20$, agreed more that graduate would rather seek employment with government/ private firm other than setting up personal business and the age group category between $36+<16-20$. The implication is that, if well motivated, younger people tend to show higher attitude/behaviour towards entrepreneurship. According to a European Union technical report prepared by [50], it is stated that youths have higher potential and prospects to become entrepreneurs. Using Germany as a case study, the report identified a wide disparity between percentage range of adults and youth engagement in entrepreneurship as $5.4 \%$ and $7.9 \%$ of adults, to $27.7 \%$ and $58.3 \%$ of youths respectively. Other interesting parts of this article has to do with the significant difference in average agreement scores for the final year students and post-graduate students with regards to the understanding that graduates would rather seek employment with government/ private firms than setting up their own business.

The analysis in table 5 indicates that the post-graduate students agreed more with question 1 (mean $=4.44$ ) than the final year full-time students (mean $=4.10$ ) that university graduates prefer jobs with the government or private firms after graduation. Similarly, final year students agreed more with question 3 (mean=4.58) than the final year post-graduate students (mean $=4.32$ ) that graduates would in the alternative prefer combining working with government/private firms to engaging in entrepreneurship or self-employment. The implication is that the intention of the student groups, on the average, remains to secure organisational employment after graduation. These findings conform to that of other empirical studies [17, 43], which argued that graduate's attitude to entrepreneurship in Nigeria is low. Conversely, other findings of this research established a significant agreement that face-to-face teaching (traditional lecturing) is mostly used in this course $(\mathrm{t}(663)=23.671 . \mathrm{p}<.0005)$; teaching and learning entrepreneurship is conducted through theoretical classes $(\mathrm{t}(655)=15.499, \mathrm{p}<.0005)$. A significant positive correlation was also established between the use of traditional lecturing and the intention to seek employment with Government or firms rather than setting up on one's own $(r=0.151, p<.0005)$. Such a positive correlation indicates that high values for the one variable are associated with high variables for the other. Earlier studies by [26, 60], agreed that the use of traditional teaching method is associated with an agreement that graduate attitudes could be biased toward organisational employment. 
Table 4. Robust analysis of the equity of means of student groups by age

\begin{tabular}{|c|c|c|c|c|c|}
\hline \multicolumn{2}{|c|}{} & Statistics & df1 & df2 & Sig. \\
\hline $\begin{array}{c}\text { 1.Prefer government / private job to } \\
\text { entrepreneurship }\end{array}$ & Welch & 2.964 & 4 & 143.080 & .022 \\
\hline $\begin{array}{c}\text { 2. Prefer government / private job first before } \\
\text { moving into entrepreneurship }\end{array}$ & Welch & .793 & 4 & 145.747 & .532 \\
\hline $\begin{array}{c}\text { 3.Prefer combining government / private job } \\
\text { with entrepreneurship }\end{array}$ & Welch & .705 & 4 & 142.567 & .590 \\
\hline
\end{tabular}

Table 5. Group statistics comparing student groups (final year and post-graduate students)

\begin{tabular}{|c|c|c|c|c|c|}
\hline \multicolumn{2}{|c|}{} & $\mathrm{N}$ & Mean & Std. Deviation & Std. Error \\
\hline $\begin{array}{c}\text { 1.Prefer government / private job to } \\
\text { entrepreneurship }\end{array}$ & Final year students & 312 & 4.10 & 1.618 & .091 \\
\cline { 2 - 6 } & Post-graduate students & 131 & 4.44 & 1.540 & .135 \\
\hline $\begin{array}{c}\text { 2. Prefer government / private job } \\
\text { first before moving into } \\
\text { entrepreneurship }\end{array}$ & Final year students & 312 & 4.73 & 1.280 & .072 \\
\cline { 2 - 7 } & Post-graduate students & 131 & 4.72 & 1.270 & .111 \\
\hline $\begin{array}{c}\text { 3.Prefer combining government / } \\
\text { private job with entrepreneurship }\end{array}$ & Final year students & 312 & 4.58 & 1.270 & .072 \\
\cline { 2 - 7 } & Post-graduate students & 131 & 4.32 & 1.294 & .114 \\
\hline
\end{tabular}

The results of the findings show that the theoretical instructions account for the largest percentage of class time used. This is confirmed by the submission that traditional lecturing method remains the most used instruction to students in Nigeria [48]. Gibeus et al.’s 2006 findings agree with the results which established the velocity: high, low or moderate level of skills in the selected universities. The findings of the article show that only $29.7 \%$ of the participants agreed that the level of skills and knowledge attained through education and training model was high or very high or extremely high while $45.0 \%$ believed that it was moderate. Conversely, about $25.0 \%$ believed that the level of skills and knowledge attainable by entrepreneurial graduates in their institution was low or extremely low. Such investigations achieved in this article conforms to earlier research by [60], which confirms low and moderate skills in entrepreneurship education in higher education institutions in Nigeria. The article concludes that entrepreneurial desirability and intentions are low because the mode of instruction largely remains academic exercises.

The influence of the method of teaching and learning is discussed. The presentations under this sub-heading analyse the influence the objective about teaching methods (cognitive and non-cognitive) as well as methods of assessment in entrepreneurship under the university education system. Table 6 below contains the analysis involving participants' opinions regarding (formal and informal) model of learning including the significance in entrepreneurial intention as follows.

The results in Table 6 reveal that $30.7 \%$ of the participants strongly agreed, $45.3 \%$ agreed and $10.3 \%$ slightly agreed that face-to-face methods were used for teaching entrepreneurship. About $86 \%$ of the participants opined that face-to-face method of teaching was used in the universities. About $18.8 \%$ strongly agreed, $41.7 \%$ agreed while $17.7 \%$ slightly agreed that entrepreneurship was taught through the conduct of theoretical classes. As a result, about $78.2 \%$ agreed that entrepreneurship was taught through theoretical classes with an average rating of $4.36(\mathrm{SD}=1.43)$. About $78 \%$ of the respondents agreed that teaching of entrepreneurship involved practical classes (mean $=4.35, \mathrm{SD}=1.50$ ), $72.2 \%$ agreed that it involved more theory than practical work (mean $=4.25, \mathrm{SD}=1.50$ ). Similarly, 76.1\% agreed that it included learning from experienced entrepreneurs and other stakeholders (mean=4.27, SD=1.41) while about $76.4 \%$ agreed that assessment area included self-practice, self-regulation and efficacy with a mean and standard deviation of 4.32 and 1.40 respectively. 
Table 6. Methods used for teaching and learning entrepreneurship

\begin{tabular}{|c|c|c|c|c|c|c|c|c|c|}
\hline & $\begin{array}{l}\text { Strongly } \\
\text { disagree }\end{array}$ & Disagree & $\begin{array}{l}\text { Slightly } \\
\text { disagree }\end{array}$ & $\begin{array}{c}\text { Slightly } \\
\text { agree }\end{array}$ & Agree & $\begin{array}{l}\text { Strongly } \\
\text { disagree }\end{array}$ & $\begin{array}{c}\text { Total } \\
\mathrm{N}=665\end{array}$ & Mean & SD \\
\hline & (1) & (2) & (3) & (4) & (5) & (6) & & & \\
\hline & n (\%) & n (\%) & n (\%) & n (\%) & n (\%) & n (\%) & & & \\
\hline Face-to-face teaching used & $\begin{array}{c}41 \\
(6.2)\end{array}$ & $\begin{array}{c}28 \\
(4.2)\end{array}$ & $\begin{array}{c}22 \\
(3.3)\end{array}$ & $\begin{array}{c}68 \\
(10.3)\end{array}$ & $\begin{array}{c}299 \\
(45.3)\end{array}$ & $\begin{array}{c}202 \\
(30.7)\end{array}$ & 660 & 4.76 & 1.37 \\
\hline $\begin{array}{l}\text { Conducted through } \\
\text { theoretical classes }\end{array}$ & $\begin{array}{c}37 \\
(5.7)\end{array}$ & $\begin{array}{c}69 \\
(10.6)\end{array}$ & $\begin{array}{c}36 \\
(5.5)\end{array}$ & $\begin{array}{c}116 \\
(17.7)\end{array}$ & $\begin{array}{c}273 \\
(41.7)\end{array}$ & $\begin{array}{c}123 \\
(18.8)\end{array}$ & 654 & 4.36 & 1.43 \\
\hline Involves practical classes & $\begin{array}{c}43 \\
(6.6)\end{array}$ & $\begin{array}{c}70 \\
(10.7)\end{array}$ & $\begin{array}{c}34 \\
(5.2)\end{array}$ & $\begin{array}{c}136 \\
(20.7)\end{array}$ & $\begin{array}{c}214 \\
(32.6)\end{array}$ & $\begin{array}{c}159 \\
(24.2)\end{array}$ & 656 & 4.35 & 1.50 \\
\hline $\begin{array}{l}\text { Involves more theory than } \\
\text { practical work }\end{array}$ & $\begin{array}{c}41 \\
(6.3) \\
\end{array}$ & $\begin{array}{c}71 \\
(10.8)\end{array}$ & $\begin{array}{c}70 \\
(10.7) \\
\end{array}$ & $\begin{array}{c}115 \\
(17.5)\end{array}$ & $\begin{array}{c}217 \\
(33.1) \\
\end{array}$ & $\begin{array}{c}142 \\
(21.6)\end{array}$ & 656 & 4.25 & 1.50 \\
\hline $\begin{array}{l}\text { Includes learning from } \\
\text { experienced entrepreneurs } \\
\text { and other stakeholders }\end{array}$ & $\begin{array}{c}39 \\
(5.9)\end{array}$ & $\begin{array}{c}60 \\
(9.1)\end{array}$ & $\begin{array}{c}58 \\
(8.8)\end{array}$ & $\begin{array}{c}144 \\
(21.9)\end{array}$ & $\begin{array}{c}241 \\
(36.6)\end{array}$ & $\begin{array}{c}116 \\
(17.6)\end{array}$ & 658 & 4.27 & 1.41 \\
\hline $\begin{array}{l}\text { Assessment area includes } \\
\text { self-practice, regulation \& } \\
\text { efficacy }\end{array}$ & $\begin{array}{c}35 \\
(5.3)\end{array}$ & $\begin{array}{c}64 \\
(9.7)\end{array}$ & $\begin{array}{c}49 \\
(7.4)\end{array}$ & $\begin{array}{c}140 \\
(21.1)\end{array}$ & $\begin{array}{c}249 \\
(37.7)\end{array}$ & $\begin{array}{c}123 \\
(18.6)\end{array}$ & 660 & 4.32 & 1.40 \\
\hline
\end{tabular}

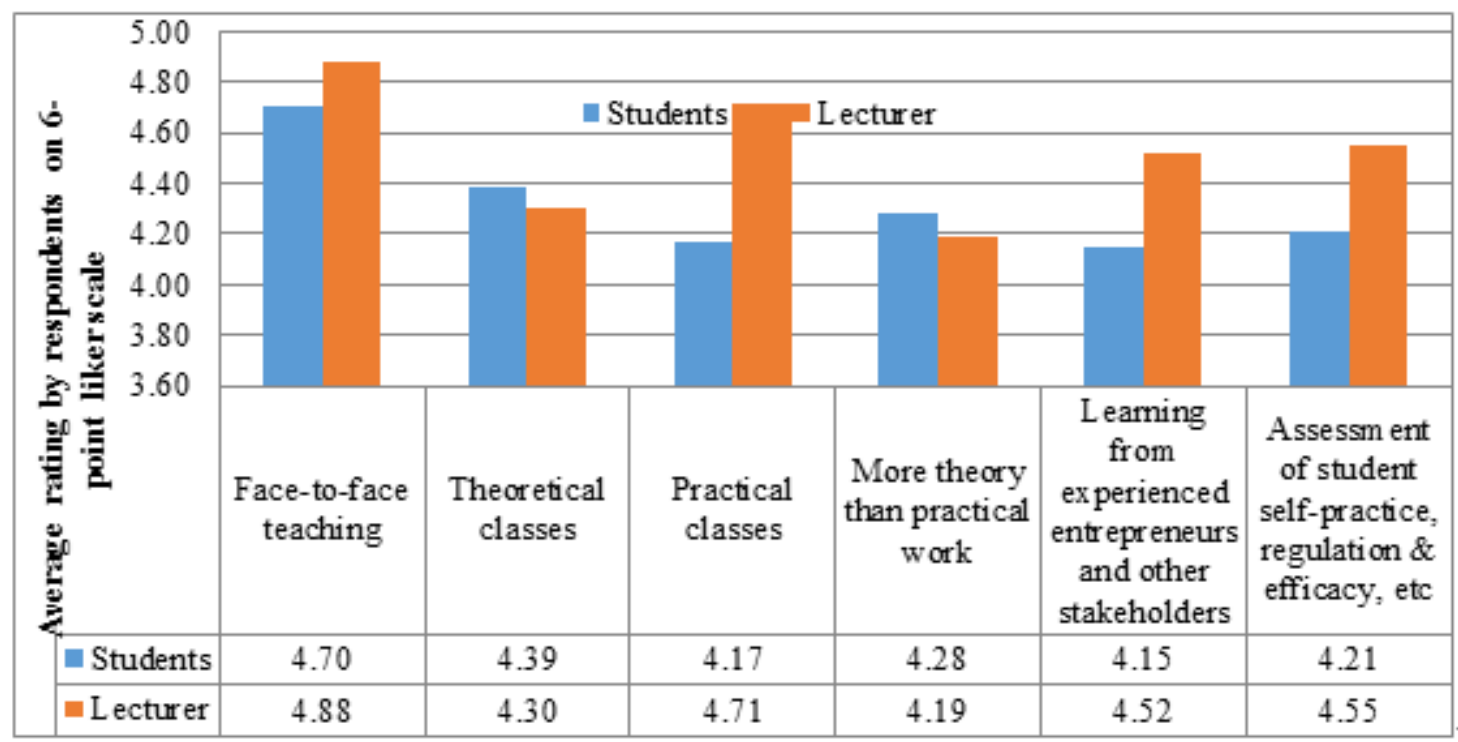

Figure 2. Methods of teaching and learning entrepreneurship

The result in figure 2, reveal that lecturers' ratings of methods of teaching and learning entrepreneurship were slightly higher than that of students, especially in agreement to the use of the face-to-face method of teaching with an average rating of 4.88 versus 4.70 , practical classes with an average rating of 4.71 versus 4.17 . The learning from experienced entrepreneurs and other stakeholders with an average rating of 4.52 versus 4.15 and assessment of students by self-practice, self-regulation and efficacy with average rating of 4.55 versus 4.21 respectively; whereas, students' ratings were slightly higher than that of the lecturers in agreement to teaching entrepreneurship using theoretical classes and more theories than practical work. The results suggested lecturers' reputation of theoretical-based teaching while the students in their rating tend to disprove high rating of non-theoretical methods. However, combining the two ratings provided an adjusted rating of methods being used for teaching and learning entrepreneurship in the selected Nigerian universities.

In another development, the results of analysis of means of the variance of equity further indicate that a significant difference in average agreement scores for the students and lecturers about the use of practical classes $(\mathrm{t}(527.199)=$ $-4.723, \mathrm{p}<.0005)$. Lecturers agree more (mean $=4.71)$ than students (mean $=4.17$ ) that this form of learning is used. The presentations in this section depict the differences of the respondents' viewpoints along different groups of universities. The findings allow the research to determine the extent of the respondents differs from teaching methods applicable to each university as presented as follow:

\subsection{Cognitive Influence of Diffused Activities in Human Capital Development}

The discussions under chapter four of this article provide indirect effects of cognitive factors as motivating factors for the human capital development of teaching and 
learning entrepreneurship. Such factors as analyses in this section of the article reveal a significant positive relationship with entrepreneurial learning outcomes. The factors including educational, social and technological variables are relevant as mediators between blended learning strategy and conventional practices towards shaping entrepreneurial desirability and behaviours. The implication is that cognitive and social learning factors are complementary to the development of entrepreneurial intention of the learning groups presented as follow:

Table 7. Ranking of learning activities

\begin{tabular}{|c|c|c|c|c|c|c|c|c|}
\hline & Never & Rarely & Sometimes & Often & Always & $\begin{array}{c}\text { Total } \\
\mathrm{N}=665\end{array}$ & Mean & SD \\
\hline & (1) & (2) & (3) & (4) & (5) & & & \\
\hline & $\mathrm{n}(\%)$ & $\mathrm{n}(\%)$ & $\mathrm{n}(\%)$ & $\mathrm{n}(\%)$ & $\mathrm{n}(\%)$ & & & \\
\hline Previous experience in an entrepreneur family & $\begin{array}{c}109 \\
(16.6)\end{array}$ & $\begin{array}{c}49 \\
(7.5)\end{array}$ & $\begin{array}{c}146 \\
(22.3)\end{array}$ & $\begin{array}{c}121 \\
(18.4)\end{array}$ & $\begin{array}{c}231 \\
(35.2)\end{array}$ & 656 & 3.48 & 1.45 \\
\hline Previous experience starting a business & $\begin{array}{c}87 \\
(13.2) \\
\end{array}$ & $\begin{array}{c}86 \\
(13.1)\end{array}$ & $\begin{array}{c}129 \\
(19.6)\end{array}$ & $\begin{array}{c}156 \\
(23.7)\end{array}$ & $\begin{array}{c}199 \\
(30.2)\end{array}$ & 658 & 3.44 & 1.39 \\
\hline Textbook presentations about entrepreneurship & $\begin{array}{c}125 \\
(19.0)\end{array}$ & $\begin{array}{c}128 \\
(19.5)\end{array}$ & $\begin{array}{c}193 \\
(29.4)\end{array}$ & $\begin{array}{c}94 \\
(14.3)\end{array}$ & $\begin{array}{c}117 \\
(17.8)\end{array}$ & 657 & 2.92 & 1.34 \\
\hline Reading business plans written by peer students & $\begin{array}{c}151 \\
(23.0)\end{array}$ & $\begin{array}{c}114 \\
(17.4)\end{array}$ & $\begin{array}{c}183 \\
(27.9)\end{array}$ & $\begin{array}{c}93 \\
(14.2)\end{array}$ & $\begin{array}{c}115 \\
(17.5)\end{array}$ & 656 & 2.86 & 1.39 \\
\hline Hearing from practicing entrepreneurs & $\begin{array}{c}38 \\
(5.8)\end{array}$ & $\begin{array}{c}39 \\
(6.0)\end{array}$ & $\begin{array}{c}115 \\
(17.6)\end{array}$ & $\begin{array}{c}170 \\
(26.0)\end{array}$ & $\begin{array}{c}292 \\
(44.6)\end{array}$ & 654 & 3.98 & 1.18 \\
\hline $\begin{array}{l}\text { Participating in a venture forum with } \\
\text { entrepreneurs' venture capitalists and service } \\
\text { providers }\end{array}$ & $\begin{array}{c}61 \\
(9.3)\end{array}$ & $\begin{array}{c}55 \\
(8.4)\end{array}$ & $\begin{array}{c}116 \\
(17.7)\end{array}$ & $\begin{array}{c}183 \\
(27.9)\end{array}$ & $\begin{array}{c}240 \\
(36.7)\end{array}$ & 655 & 3.74 & 1.29 \\
\hline $\begin{array}{l}\text { Hearing the instructor's experiences as a small } \\
\text { business owner/operator }\end{array}$ & $\begin{array}{c}39 \\
(6.0)\end{array}$ & $\begin{array}{c}61 \\
(9.3)\end{array}$ & $\begin{array}{c}146 \\
(22.3)\end{array}$ & $\begin{array}{c}185 \\
(28.2)\end{array}$ & $\begin{array}{c}224 \\
(34.2)\end{array}$ & 655 & 3.76 & 1.19 \\
\hline Interviewing a practicing entrepreneur & $\begin{array}{c}73 \\
(11.1)\end{array}$ & $\begin{array}{c}77 \\
(11.7)\end{array}$ & $\begin{array}{c}124 \\
(18.9)\end{array}$ & $\begin{array}{c}180 \\
(27.4)\end{array}$ & $\begin{array}{c}202 \\
(30.8)\end{array}$ & 656 & 3.55 & 1.33 \\
\hline $\begin{array}{l}\text { Talking to other students about their } \\
\text { entrepreneurial intentions }\end{array}$ & $\begin{array}{c}117 \\
(17.8)\end{array}$ & $\begin{array}{c}119 \\
(18.1)\end{array}$ & $\begin{array}{c}180 \\
(27.4)\end{array}$ & $\begin{array}{c}118 \\
(18.0)\end{array}$ & $\begin{array}{c}122 \\
(18.6)\end{array}$ & 656 & 3.02 & 1.35 \\
\hline $\begin{array}{l}\text { Examining websites dedicated to } \\
\text { entrepreneurship }\end{array}$ & $\begin{array}{c}92 \\
(14.0)\end{array}$ & $\begin{array}{c}82 \\
(12.5)\end{array}$ & $\begin{array}{c}198 \\
(30.2)\end{array}$ & $\begin{array}{c}120 \\
(18.3)\end{array}$ & $\begin{array}{c}162 \\
(24.8)\end{array}$ & 655 & 3.27 & 1.34 \\
\hline $\begin{array}{c}\text { Reading about entrepreneurs in the current } \\
\text { news }\end{array}$ & $\begin{array}{c}72 \\
(11.0)\end{array}$ & $\begin{array}{c}91 \\
(13.9)\end{array}$ & $\begin{array}{c}159 \\
(24.3)\end{array}$ & $\begin{array}{c}147 \\
(22.5)\end{array}$ & $\begin{array}{c}185 \\
(28.3)\end{array}$ & 654 & 3.43 & 1.33 \\
\hline Reading about entrepreneurs in history & $\begin{array}{c}104 \\
(15.9)\end{array}$ & $\begin{array}{c}94 \\
(14.4)\end{array}$ & $\begin{array}{c}159 \\
(24.3)\end{array}$ & $\begin{array}{c}133 \\
(20.3)\end{array}$ & $\begin{array}{c}164 \\
(25.1)\end{array}$ & 654 & 3.24 & 1.39 \\
\hline Seeing videos about entrepreneurs & $\begin{array}{c}92 \\
(14.1)\end{array}$ & $\begin{array}{c}96 \\
(14.7)\end{array}$ & $\begin{array}{c}135 \\
(20.6)\end{array}$ & $\begin{array}{c}162 \\
(24.8)\end{array}$ & $\begin{array}{c}169 \\
(25.8)\end{array}$ & 654 & 3.34 & 1.37 \\
\hline $\begin{array}{l}\text { Listening to theoretical lectures about } \\
\text { entrepreneurship in the classroom }\end{array}$ & $\begin{array}{c}96 \\
(14.7)\end{array}$ & $\begin{array}{c}113 \\
(17.3)\end{array}$ & $\begin{array}{c}170 \\
(26.0)\end{array}$ & $\begin{array}{c}118 \\
(18.0)\end{array}$ & $\begin{array}{c}158 \\
(24.1)\end{array}$ & 655 & 3.20 & 1.37 \\
\hline $\begin{array}{c}\text { Writing and exchanging business plans, cards } \\
\text { with entrepreneurs, angel investors and service } \\
\text { providers. }\end{array}$ & $\begin{array}{c}69 \\
(10.6)\end{array}$ & $\begin{array}{c}72 \\
(11.0)\end{array}$ & $\begin{array}{c}161 \\
(24.6)\end{array}$ & $\begin{array}{c}148 \\
(22.6)\end{array}$ & $\begin{array}{c}203 \\
(31.0)\end{array}$ & 654 & 3.53 & 1.31 \\
\hline
\end{tabular}

Source: Fieldwork 2016 


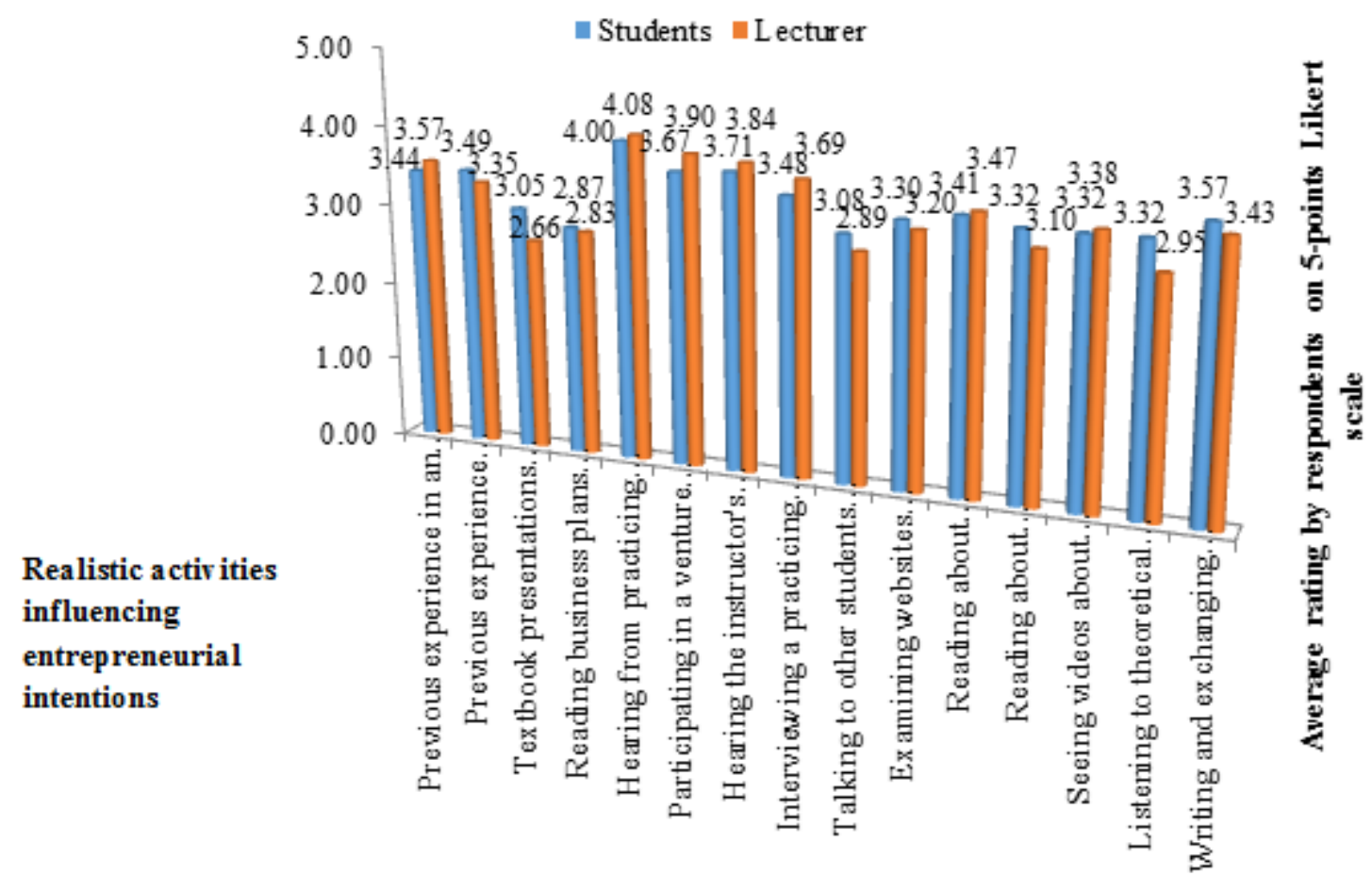

Figure 3. Realistic activities and entrepreneurial intention

The results as depicted in Table 7 reveal the realistic activities are influencing graduates' entrepreneurial intentions and practice. The result found and reported that more than half of the studied participants opined that realistic activities such as previous experience in an entrepreneur family (mean=3.48, $\mathrm{SD}=1.45$ ), previous experience in starting a business (mean $=3.44, \mathrm{SD}=1.39$ ), hearing from entrepreneurs (mean $=3.98, \mathrm{SD}=1.18$ ) were effective to students. This also includes participating in a venture forum with entrepreneurs (mean=3.74, $\mathrm{SD}=1.29$ ), hearing instructors' experiences as a small business owner (mean=3.76, $\quad \mathrm{SD}=1.19$ ), interviewing a practising entrepreneur (mean=3.76, SD=1.19). Also, methods relating to reading about entrepreneurs in the news (mean=3.43, SD=1.33), seeing videos about entrepreneurs (mean=3.34, SD=1.37) and writing and exchanging business plans with entrepreneurs (mean $=3.53, \mathrm{SD}=1.31$ ) do often or always influence graduates' entrepreneurial intentions and practice, while others were perceived to be less influential.

The result in figure 3, revealed that lecturers' ratings of realistic activities influencing entrepreneurship were slightly higher than that of students. The rating especially in their agreement on the influence of seeing videos about entrepreneurs with an average rating of 3.38 versus 3.32, reading about entrepreneurs in the current news (3.47 versus 3.41 ). This also includes interviewing a practicing entrepreneur (3.69 versus 3.48), hearing the instructor's experiences as a small business owner/operator (3.84 versus 3.71), participating in a venture forum with entrepreneurial venture capitalists and service providers (3.90 versus 3.67 ), hearing from practicing entrepreneurs (4.08 versus 4.00) and previous experience in an entrepreneur family, 4.55 versus 4.21 respectively. Conversely, students had higher average ratings in other realistic activities. Since there were no wide disparities in the ratings of the two categories of the respondents, the results suggested the views of lecturers agreed with that of the students on realistic activities influencing entrepreneurial intentions and practised among graduates of selected Nigerian universities.

\subsection{Mediating Effects of Entrepreneurial Orientation Strategies on Entrepreneurial Behaviour}

The analyses relating to the research question three, presenting the perceived relevance of entrepreneurship orientation to drive for entrepreneurial activities in the selected universities, are discussed. The presentations under this section provide what respondents points of view are to the level of influence of influence achievable through entrepreneurial orientation activities in the context of universities in Nigeria. Also revealing are the results as presented below that show the perceptions of the respondents as follows: 
Table 8. Relevance of entrepreneurial orientation in entrepreneurial intention

\begin{tabular}{|c|c|c|c|c|c|c|c|c|c|}
\hline & $\begin{array}{l}\text { Strongly } \\
\text { disagree }\end{array}$ & Disagree & $\begin{array}{l}\text { Slightly } \\
\text { disagree }\end{array}$ & $\begin{array}{c}\text { Slightly } \\
\text { agree }\end{array}$ & Agree & $\begin{array}{c}\text { Strongly } \\
\text { agree }\end{array}$ & $\begin{array}{c}\text { Total } \\
\mathrm{N}=665\end{array}$ & Mean & SD \\
\hline & (1) & (2) & (3) & (4) & (5) & 6 & & & \\
\hline & $\mathrm{n}(\%)$ & n(\%) & $\mathrm{n}(\%)$ & n(\%) & $\mathrm{n}(\%)$ & n(\%) & & & \\
\hline $\begin{array}{l}\text { Student internship } \\
\text { experience helps to relate } \\
\text { the theories learnt in the } \\
\text { classroom with the work } \\
\text { environment. }\end{array}$ & $\begin{array}{c}16 \\
(2.4)\end{array}$ & $\begin{array}{c}20 \\
(3.0)\end{array}$ & $\begin{array}{c}17 \\
(2.6)\end{array}$ & $\begin{array}{c}102 \\
(15.5)\end{array}$ & $\begin{array}{c}295 \\
(44.8)\end{array}$ & $\begin{array}{c}208 \\
(31.6)\end{array}$ & 658 & 4.936 & 1.048 \\
\hline $\begin{array}{c}\text { Student internship } \\
\text { attachment provides } \\
\text { necessary job experience } \\
\text { that can improve chances } \\
\text { for employment upon } \\
\text { graduation. }\end{array}$ & $\begin{array}{c}10 \\
(1.5)\end{array}$ & $\begin{array}{c}23 \\
(3.5)\end{array}$ & $\begin{array}{c}23 \\
(3.5)\end{array}$ & $\begin{array}{c}100 \\
(15.2)\end{array}$ & $\begin{array}{c}285 \\
(43.3)\end{array}$ & $\begin{array}{c}217 \\
(33.0)\end{array}$ & 658 & 4.956 & 1.006 \\
\hline $\begin{array}{l}\text { Mentoring experiences } \\
\text { help to improve graduate } \\
\text { personal confidence and } \\
\text { self-esteem. }\end{array}$ & $\begin{array}{c}5 \\
(0.8)\end{array}$ & $\begin{array}{c}11 \\
(1.7)\end{array}$ & $\begin{array}{c}17 \\
(2.6)\end{array}$ & $\begin{array}{c}80 \\
(12.2)\end{array}$ & $\begin{array}{c}329 \\
(50.1)\end{array}$ & $\begin{array}{c}215 \\
(32.7)\end{array}$ & 657 & 5.012 & 0.974 \\
\hline $\begin{array}{c}\text { The mentoring } \\
\text { experiences help to } \\
\text { develop problem solving } \\
\text { skills. }\end{array}$ & $\begin{array}{c}14 \\
(2.1)\end{array}$ & $\begin{array}{c}18 \\
(2.7)\end{array}$ & $\begin{array}{c}13 \\
(2.0)\end{array}$ & $\begin{array}{c}95 \\
(14.5)\end{array}$ & $\begin{array}{c}327 \\
(49.8)\end{array}$ & $\begin{array}{c}189 \\
(28.8)\end{array}$ & 656 & 5.006 & 0.953 \\
\hline $\begin{array}{l}\text { Conference and seminar } \\
\text { experiences provide } \\
\text { insights into business } \\
\text { ideas and potential } \\
\text { threats. } \\
\end{array}$ & $\begin{array}{c}10 \\
(1.5)\end{array}$ & $\begin{array}{c}15 \\
(2.3)\end{array}$ & $\begin{array}{c}8 \\
(1.2)\end{array}$ & $\begin{array}{c}118 \\
(18.0)\end{array}$ & $\begin{array}{c}310 \\
(47.2)\end{array}$ & $\begin{array}{c}195 \\
(29.7)\end{array}$ & 657 & 5.018 & 0.972 \\
\hline $\begin{array}{l}\text { Conference and seminar } \\
\text { experiences help } \\
\text { graduates to identify their } \\
\text { weaknesses and strengths }\end{array}$ & $\begin{array}{c}10 \\
(1.5)\end{array}$ & $\begin{array}{c}9 \\
(1.4)\end{array}$ & $\begin{array}{c}20 \\
(3.1)\end{array}$ & $\begin{array}{c}92 \\
(13.8)\end{array}$ & $\begin{array}{c}317 \\
(48.4)\end{array}$ & $\begin{array}{c}207 \\
(31.6)\end{array}$ & 655 & 4.921 & 1.110 \\
\hline $\begin{array}{l}\text { Business networking } \\
\text { exposure motivates job } \\
\text { creation ability and } \\
\text { competency. }\end{array}$ & $\begin{array}{c}10 \\
(1.5)\end{array}$ & $\begin{array}{c}9 \\
(1.4)\end{array}$ & $\begin{array}{c}17 \\
(2.6)\end{array}$ & $\begin{array}{c}92 \\
(14.0)\end{array}$ & $\begin{array}{c}334 \\
(50.7)\end{array}$ & $\begin{array}{c}197 \\
(29.9)\end{array}$ & 659 & 4.942 & 1.085 \\
\hline $\begin{array}{l}\text { Business networking } \\
\text { experience enhances } \\
\text { business idea start-up, } \\
\text { sustenance and growth. }\end{array}$ & $\begin{array}{c}9 \\
(1.4)\end{array}$ & $\begin{array}{c}11 \\
(1.7)\end{array}$ & $\begin{array}{c}20 \\
(3.0)\end{array}$ & $\begin{array}{c}89 \\
(13.5)\end{array}$ & $\begin{array}{c}320 \\
(48.6)\end{array}$ & $\begin{array}{c}210 \\
(31.9)\end{array}$ & 659 & 5.073 & 0.906 \\
\hline
\end{tabular}

The results in table 8 depict the relevance of entrepreneurial orientation in motivating graduates entrepreneurial drive. According to the result, the majority (91.9\%) of the respondents agreed that student internship experience helped to relate the theories learnt in the classroom with the work environment. The ratings producing a mean and standard deviation of 4.94 and 1.05 respectively; $91.5 \%$ agreed that student internship attachment provided necessary job experience that can improve chances for employment upon graduation (mean=4.96, SD=1.01). Around $95.0 \%$ opined that mentoring experiences helped to improve graduate personal confidence and self-esteem (mean $=5.01$,
$\mathrm{SD}=0.97) ; 93.1 \%$ supported that the mentoring experiences helped to develop problem-solving skills (mean $=5.01$, $\mathrm{SD}=0.95$ ). About $95 \%$ opined that conference and seminar experiences provide insights into business ideas and potential threats (mean $=5.02, \mathrm{SD}=0.97$ ); about $94 \%$ were of the view that conference and seminar experiences help graduates to identify their weaknesses and strengths (mean=4.92, SD=1.11). About $94.6 \%$ believed that business networking exposure motivates job creation ability and competency (mean $=4.94, \mathrm{SD}=1.09$ ) while $94 \%$ agreed that business networking experience enhances business idea startup, sustenance and growth (mean $=5.07$, $\mathrm{SD}=0.91)$. 


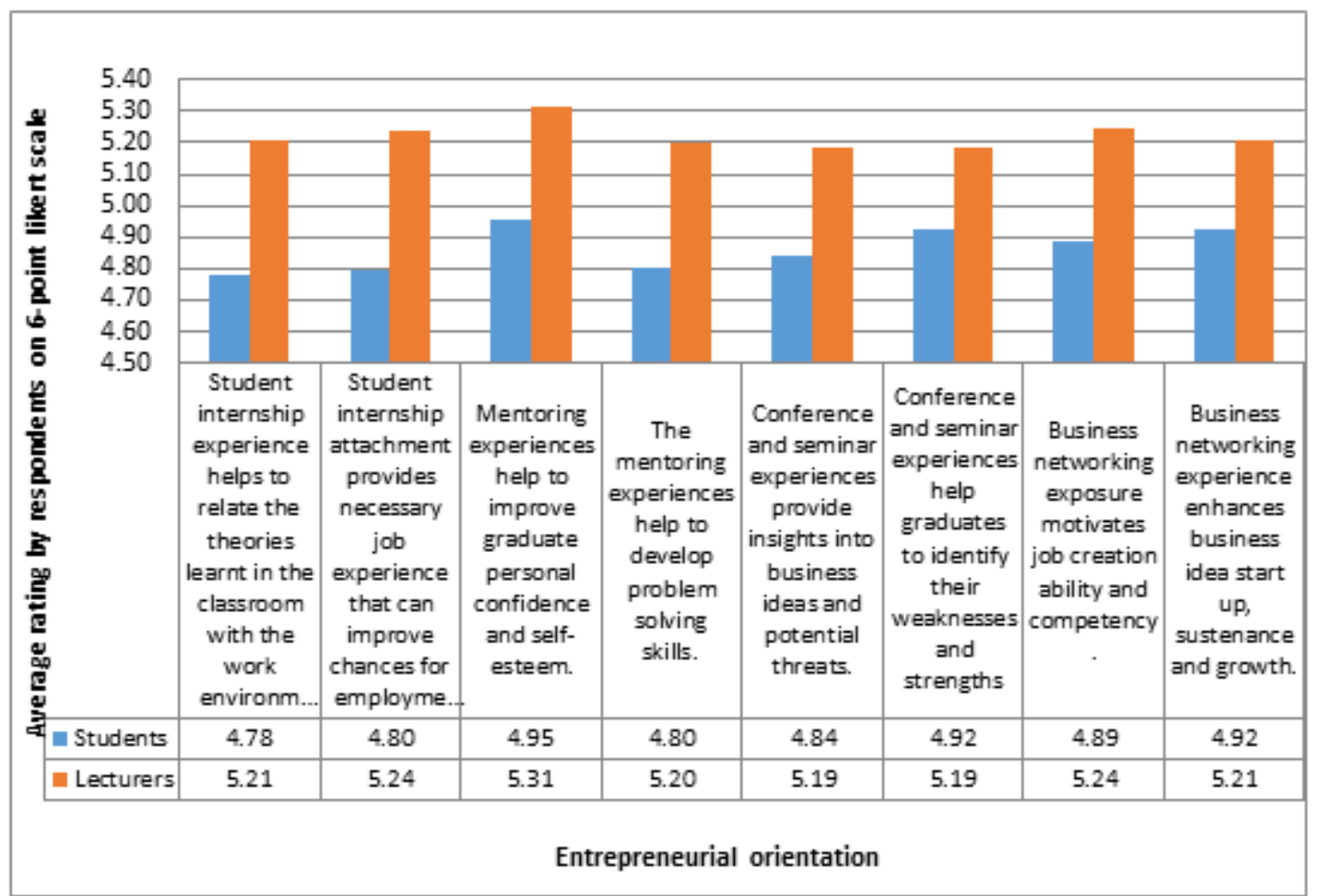

Figure 4. Relevance of entrepreneurial orientation

The results of the analysis in figure 4 reveal students' and lecturers' rating of the relevance of entrepreneurial orientation in motivating graduates towards entrepreneurship. According to the result, both students and lecturers rated each item high; however, the average opinion of lecturers (5.21) that student internship experience helped to relate the theories learnt in the classroom with the work environment was higher compared to that of the students (4.78). This pattern of average rating was similar to the views that student internship attachment provided necessary job experience that can improve chances for employment upon graduation (5.24 versus 4.80 ), that mentoring experiences helped to improve graduate personal confidence and self-esteem (5.31 versus 4.95 ).

The mentoring experiences help to develop problem-solving skills (5.20 versus 4.80 ), and conference and seminar experiences provide insights into business ideas and potential threats (5.19 versus 4.84). Similarly, conference and seminar experiences help graduates to identify their weaknesses and strengths (5.19 versus 4.92), that business networking exposure motivates job creation ability and competency (5.24 versus 4.89 ) while that business networking experience enhances business idea startup, sustenance and growth (5.21 versus 4.92). This result found that virtually all the lecturers who are assumed to have better knowledge and clearer perception due to their experience in the field agreed that the various items of entrepreneurial orientation are relevant in motivating graduates' entrepreneurial drive.

\subsection{Complementary Framework for University-level Entrepreneurship Training}

As a benchmark for learning entrepreneurship [5, 27], University-level entrepreneurship training is demanding to understanding the list of cognitive and non-cognitive skills. This is in agreement with similar empirical research cited in [40], also view that the kind of signal students receive from learning entrepreneurship will go a long way to determine individual learning outcomes. Similar studies by [42, 57], provides insights into the linkages that exist between adopted learning strategies and the desired learning outcomes. It is argued that even though the use of traditional learning methods may be limited in term of scope, the schools of thoughts in [51] describe the tendency of the methods if complemented with other innovations. The implication is that the sustainability of entrepreneurship education is enhanced if the approach to teaching and learning is project-based, collaboration and community driven. If entrepreneurship education is built around these concepts, then the result is likely to lead to motivating drive for entrepreneurship [11, 24]. Consequently, this article provided a conceptual framework reflecting the complementary nature under which teaching and learning entrepreneurship at the university could be determined as follows in the figure below. 


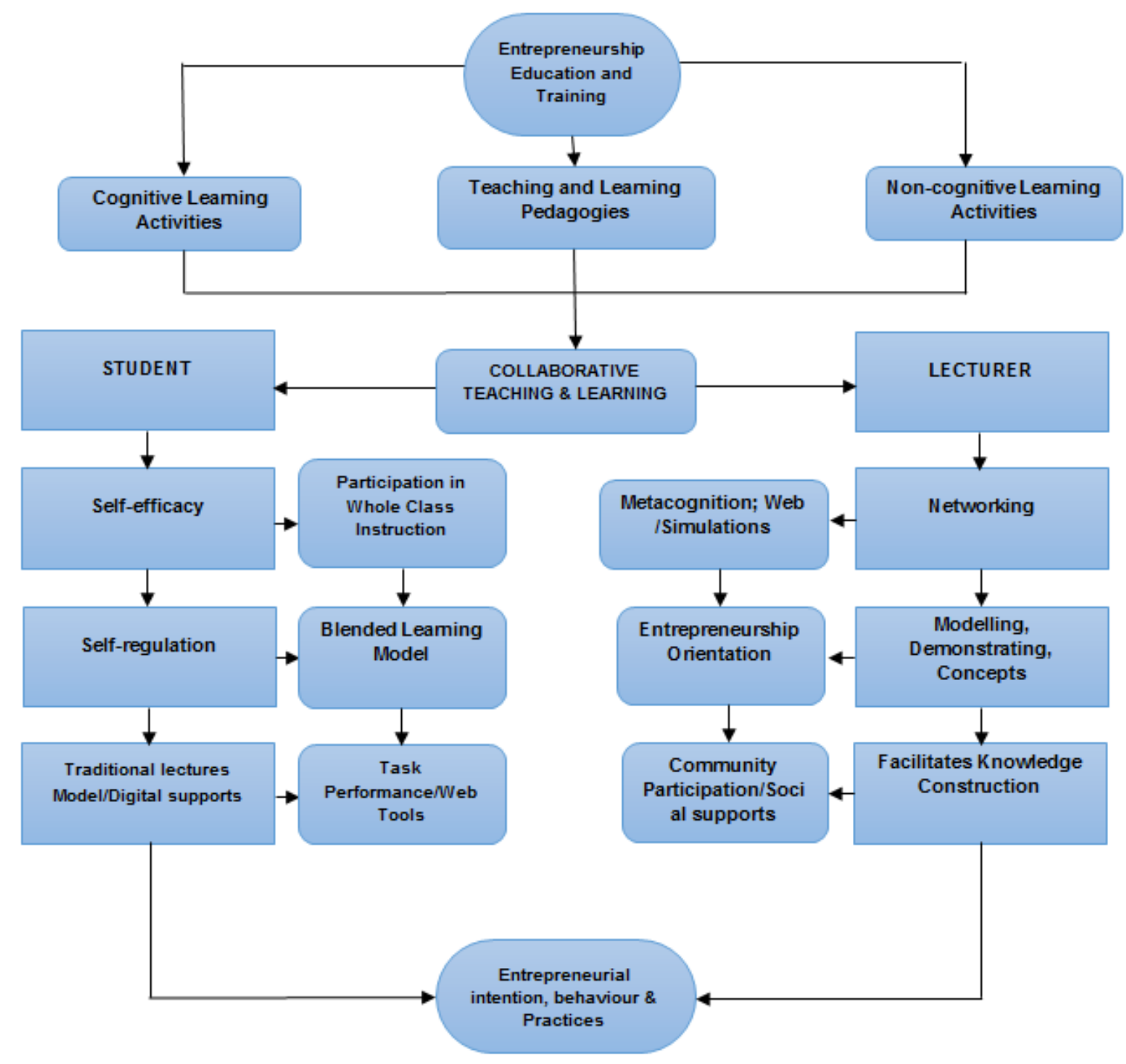

Author's concept

Figure 5. Framework for university entrepreneurship education and training

Figure 5 provides an integrated a framework for entrepreneurship education and training, around which the university could be pursued human capital development. The framework provides a synergy between students' and lecturers' activities in the university-level entrepreneurship teaching and learning. The lecturers perform the role of planning, teaching and facilitating the sequence of learning taking into consideration the relevance of technology supports. Similarly, students construct and demonstrate knowledge from the experiential feedback blend with technological innovation (constructivism, interactive sessions and the use of web tools). The figure further explains students' and teachers' actions, which includes knowledge construction, knowledge display and collaboration on the part of the students. The teacher action in the interactive learning processes includes interactive planning, interactive teaching and facilitation with other experts or practitioners. Such learning framework promotes collaborative learning when two or more people learn together which include learning from the expertise within a professional community.

This framework is supported by separate studies conducted by [3], which demonstrate collaborative learning exercises as a convergence or construction of a shared meaning that relates to conventional analysis, which encourages the learning audience to reach a convergent thought. Interactive teaching affects interactive learning; such relationship is made possible through interactive planning, interactive teaching and facilitation in the context of teaching which produces knowledge construction, knowledge display and collaboration in the context of learning. Such convergence is further demonstrated through Theory $\mathrm{U}$, which involves the creation of knowledge and transfer in the context of entrepreneurship education and training. The implication is that when experiential teaching activities are employed and when self-reflection of the thoughts and beliefs are encouraged among students, the interrelationship derivable could result 
in significant personal intentions and insights.

The implication is that an effective teaching and learning framework is deemed to be engaging and proficient in curriculum design, project-based-learning, new forms of peer and group assessments, regional networking, as well as more conventional class teaching. Without designing and implementing such a pedagogical framework to address the learning gaps, [25] maintained that the performances of most students in entrepreneurship development programmes would remain mostly average or below average. This finding is equally supported by [1], who noted that the perpetual students' low educational performance is largely due to ineffectively chosen teaching and learning methods. Similarly, the argument is that learners that are highly educated and innovatively trained are likely to exhibit higher performances compared to those that lack these key resources [63]. The reason is that well-educated and trained learners are proactive and quick at learning and applying new skills to improve efficiency, productivity, risk-taking and innovativeness [41]. The knowledge-based theory also distinguishes between two types of learning based on the context of which it occurs. The concept exploitative learning is externally related activities that must be acquired in addition to the explorative learning which takes place within the classroom settings or internal experiments.

This framework is related to the Kolb Learning Theory, which relates effective education and training to learning the theory and practice of entrepreneurship [35]. The framework as provided in this journal article aligns with [51] research, which explains that experiential learning and learning by doing are fundamental processes of knowledge development for entrepreneurs. Consequently, the level of education and training can positively influence the innovativeness and risk-taking behaviour.

\section{Conclusions}

The trends around the world suggest that effective teaching and learning entrepreneurship requires education and training framework. This empirical article established a nexus between the adopted strategies for the teaching of entrepreneurship and the influence on learning outcomes in the selected universities in southwest, Nigeria. Similarly, the article identified a gap in the current practices which is still substantially traditional in operation. Exposure of students to the industrial/field works is still insignificant. At the moment, a centralised training technique is adopted to impart entrepreneurial knowledge to students. Entrepreneurship courses are offered as compulsory general courses to all students irrespective of their career choices, interests and academic disciplines. More of theoretical classes are conducted through traditional face-to-face lectures in the classroom. There are attempts to engage students on few of practical skills ranging from tailoring, soap making, catering, shoe making, bead making and the rest in entrepreneurship development centres.

The focus however is restricted to those vocations in which the universities have the capacities, skilled personnel and equipment. It is important to underscore the fact that many of the lecture theatres use for learning are ill-equipped with modern technological apparatus while overcrowded students attendance are witnessed mostly during class sessions. This is at variance with blended learning delivery approach to instructions. Further contributions to knowledge are made through aggregation of methods including self-regulation, self-efficacy, and entrepreneurship orientation as mediating variables to scale-up entrepreneurial desires. The article determined areas of overlap between the experiential teaching activities, traditional lecturing method and the influence on entrepreneurial learning processes. This led to a redirection through a conceptual framework designed and supported by the respondents in the universities selected for the study.

The idea of centralising the teaching and learning of entrepreneurship across the university system might therefore need to be redirected. There is always an element of the entrepreneurship component in every academic career. These components need to be identified and offered at the departmental levels to all interested students irrespective of their course of study. Students interdisciplinary through department exchange training programme might be ideal at bridging the dichotomy. There is the need to review of existing entrepreneurship curricula with a view of strengthening them for better performance. The article canvassed the use of blended approaches including successful entrepreneurs being invited as guest speakers, sending students on internships, using simulations, networking, mentoring and coaching to stimulate teaching and learning of entrepreneurship in Nigerian universities. The article therefore invited the attentions of National University Commission, university management, researchers and other entrepreneurial stakeholders to the need for a shift in highly curriculum content-based approach to a more inclusive outcome-based model more of collaboration, partnership and inclusiveness.

\subsection{Managerial Implications of the Findings}

The findings of this article show that the task of imparting entrepreneurial skills requires aggregation of knowledge with other knowledge providers. It is anticipated that higher education institutions would pursue cardinal methods to realise the objectives of entrepreneurship education and training such as: inculcating drive for identifying business opportunities and exploiting the opportunities in a way that solve problems in the society, providing relevant exposure to require skills for establishing new business ventures, management, 
growth, and development as well as motivating individual entrepreneurial intention, culture, and behaviour through self-efficacy design programmes and regulations. Recommendations therefore include the need for National University Commission to develop a modified curriculum which strikes a balance between theory and practical approach to learning entrepreneurship at Nigerian universities. The curriculum should engage undergraduates more in practical activities through complementary activities by cross-disciplinary exchange training, family mentoring, self-regulation, industrial attachment, networking, internship and business simulations. Rather than a centralised teaching and learning format in place at most universities in Nigeria, teaching entrepreneurship should be decentralised and offered based on interest, at the departmental/faculty levels to all categories of students, irrespective of academic disciplines. There should be a new national policy guideline allocating $70 \%$ practical activities to entrepreneurship classes at the levels of department or faculty of participating students, since there is always an element of entrepreneurship components in every academic career.

There should be more national advocacy to all stakeholders on the need to provide effective entrepreneurial education vis-à-vis the value chain to the economy. The article also established the significance including other stakeholders within and outside the university communities to provide hands on training for the benefits of both the lecturers and students. The teaching and learning of entrepreneurship should begin at the foundation level of the courses of study as against the current final-year class arrangement, when students are about to depart the universities. Government through the university authorities should make funding assistance available to undergraduates and alumni to establish income generating ventures. The assessment and evaluation should not be limited to written examinations but physical projects that can be showcased. Entrepreneurship Development Centres in each university should play more of incubatory and monitoring roles. The framework should not only be limited to the undergraduates but the database of alumni should also be created while feedback and post-study technical supports are provided graduating students.

\section{REFERENCES}

[1] Adunola, O. (2011). The impact of teachers' teaching methods on the academic performance of primary school pupils in Ijebu-Ode Local Area of Ogun State,” Ogun State, Nigeria: Ego Booster Books. https://pdfs.semanticscholar.o rg/40b7/f0866a3fc65a151a5f13b797c96cf01506f1.pdf

[2] Afolabi, A. (2015). The effect of entrepreneurship on economic growth and development in Nigeria. International Journal of Development and Economic Sustainability, 3(2),
49-65.

[3] Akinboye, A.K. \& Pihie Z.A.L. (2014). Effects of learning styles on students' perceptions of entrepreneurship course relevance and teaching methods. International Interdisciplinary Journal of Education, 3(1), 217-224.

[4] Aladekomo, F.O. (2004). Nigeria educational policy and entrepreneurship. Journal of Social Science, 9(2), 75-87.

[5] Ali, I., \& Muhammad, R.R. (2012). The Influence of teaching approaches among technical and vocational education teachers towards acquisition of entrepreneurship skills in Kano State-Nigeria. Journal of Humanities and Social Science, 5, (3), 19-22.

[6] Arasti, Z., Falavarjani, M.K., \& Imanipour, N. (2012). A study of teaching methods in entrepreneurship education for graduate students. Higher Education Study, 2(1), 2-10. https://eric.ed.gov/?id=EJ1081428

[7] Baba, G.K. (2013). The challenges of entrepreneurship development in Nigeria and way forward. Journal of Business and Organizational Development, 5(1), 54 - 64.

[8] Ball, D.L. \& Forzani, F.M. (2009). The work of teaching and the challenge for teachers' education. Journal of Teacher Education, 60(5), 497-51.

[9] Bechard, J.P., \& Gregoire, D. (2005). Entrepreneurship education research revisited: The case of higher education. Academy of Management Learning and Education, 4(1), 22-43.

[10] Bicaba, Z., Brixiova, Z. \& Ncube, M. (2014). Skills and youth entrepreneurship in Africa: analysis with evidence from Swaziland. Available online: wp1077.pdf.

[11] Capelo, A., Santos, C. \& Pedrosa, M. A. (2014). Education for sustainable development in East Timor, case study. Asia Education and Development Studies, 3(2).

[12] Collins, K., Hannon, P.D. \& Smith, A. (2004). Enacting entrepreneurial intent: the gaps between student needs and higher education capability. Education and Training, 46 (8/9), 454-463.

[13] Colin, J. \& Jack, E. (2004). A contemporary approach to entrepreneurship education. Journal of education and training, 46(8/9), 416-423.

[14] Costello, G.J. (2016). Incubation center and teaching of entrepreneurship bridging theory and practice. All Irland Journal of Teaching and Learning in Higher Education, 8(1), 2421-2444.

[15] Daniela M., Rainer, H., Norbert, K. \& Birgit, W. (2016). The impact of entrepreneurship education on the entrepreneurial intention of students in science and engineering versus business studies university programs. Technological Forecasting and Social Change. 104, 172179.

[16] Dickson, P.H., Solomon, G.T. \& Weaver, K.M. (2008). Entrepreneurial selection and success: Does education matter? Journal of Small Business and Enterprise Development, 15(2), 239-258.

[17] Ekundayo, B.B. \& Babatunde, E.D. (2014). The impact of entrepreneurship education on entrepreneurial intentions among Nigerian undergraduates. International Journal of 
Research in Humanities, Arts and Literature, 2, 11:15-26.

[18] European Commission (EU, 2012). A guiding framework for the entrepreneurial university. OECD, 1-53. Available: ec-oecd entrepreneurial university framework.pdf.

[19] Ewens, M. \& Townsend, R.R. (2017). Investors and the entrepreneurship gender gap. California Institute of Technology, Townsend: University of California, San Diego. Available: wpcarey.asu.edu/sites/default/files/mich ael_ewens_seminar_march_24_2017.pdf

[20] Fayolle, A. \& Linan, F. (2014). The future of research on entrepreneurial intentions. Journal of Business Research, 67(5), 663-666.

[21] Fayomi, E.J., \& Fields, Z. (2016). Curriculum content reform and graduate entrepreneurial training in Nigerian university, International Journal of Education Science, 14(1, 2), 121-129.

[22] Frank, J. \& Klar, B. (2016). Methods to test for equality of two normal distributions. Statistical Methods and Application, 25: 581-599.

[23] Frederick, H. H. (2007). Blended Learning in Entrepreneurship Education in the Asia-Pacific: A Grounded Approach to Entrepreneurship Pedagogy, In Small Enterprise Conference, 2326 Sep 2007, Unitec Business School, Auckland. 91.

[24] Ganiee, F.A (2014). Education as an instrument of social change. International Journal of English Language Literature and Humanities, II (I), 18-24.

[25] Ganyanpful, E.M. (2013). Teaching methods and students' academic performance. International Journal of Humanities and Social Sciences Invention, 2(9), 29-35.

[26] Garba, A.S. (2010). Refocusing education system towards entrepreneurship development in Nigeria: a tool for poverty eradication. European Journal of Social Sciences, $15,140-150$.

[27] Gibbs, A., Hannon, P., Price, A., Robertson, I. (2013). A compendium of pedagogies for teaching entrepreneurship. Retrieved from: http://ncee.org.uk/wp-content/uploads/201 3/12/Compendium-of-Pedagogies.pdf

[28] Israel, G.D. (2009). Determining sample size: Institute of Food and Agricultural Sciences (IFAD), University of Florida. Document PEOD6. Retrieved from: http/edis.ifas.ufl.edu.

[29] Jackson, T. (2015). Entrepreneurship training in tertiary education: Its development and transfer. Local Economy, $1-19$.

http://journals.sagepub.com/doi/abs/10.1177/02690942155 89143

[30] Jin, Q., Gilmartin, S.K., Sheppard, S.D. \& Chen, H.L. (2015). Comparing engineering and business undergraduate students' entrepreneurial interests and characteristics. The Journal of Engineering Entrepreneurship, 6, (2), 1-24.

[31] Kayle, C. \& Olen, G. (2017). Fostering generative conversation in higher education course discussion boards. Innovations in Education and Teaching International, 54(4), $1-9$.
[32] Kleeman, M (2011). Insights into entrepreneurship education: Integrating innovating teaching practices. Master thesis in business administration. Jonkoping International Business School, 1-68.

[33] Koe, W. (2016). The relationship between individual entrepreneurial orientation (IEO) and entrepreneurial intention. Journal of Global Entrepreneurship, 6(13). Available online: https://doi.org/10.1186/s40497-016-0057 $-8$

[34] Kolb, D. A. (1984). Experiential learning: experience as the source of learning and development. New Jersey, Prentice Hall:

[35] Kolb, D.A (2015). Experiential learning: experience as a source of learning and development, $2^{\text {nd }}$ Edition. New Jessy: Pearson Education. Inc.

[36] Kuratko, D.F. (2005). The emergence of entrepreneurship education: development, trends, and challenges. Entrepreneurship, Theory and Practice, 29, 577-597.

[37] Lai, K. W., Khaddage, F. \& Knezek, G. (2013). Blending student technology experiences in formal and informal learning. Journal of Computer Assisted Learning, 29 (5), 414-425.

[38] Lekang, B., Nain, M.S., Singh, R. \& Sharma, J.P. (2016). Explanatory variables for the perceived utility of experiential learning programme of Indian council of agricultural research. Journal of Community and Sustainable Development, 11(1), 1-8.

[39] Mamman, A. (2014). Effect of entrepreneurship education on capacity building in small and medium scale enterprises (SMEs) in Nigeria. International Journal of Social Sciences and Entrepreneurship, 1(11), 224-235.

[40] Maritz, P.A., Brown, C. \& Shieh, C.J. (2010). A blended learning approach to entrepreneurship education. Actual Problems of Economics, 12(2), 83-93.

[41] Martin C. \& Lucu, R. (2014). Teaching entrepreneurship to educational sciences students. Procedia- Social and Behavioural Sciences, 116, 4397-4400. https://core.ac.uk/download/pdf/82036757.pdf

[42] Mkala, M., \& Wanjua, K. (2013). Transforming Implementation of Entrepreneurship Education Programme in Technical Training Institutes in Kenya. European Journal of Business and Innovation Research, 3, 18-27.www.eajournals.org/wp-content/uploads/TRANSFO RMING-IMPLEMENTATION-OF-ENTREPRENEURSH IP-EDUCATION-PROGRAMME-IN-TECHNICAL-TRA INING-INSTITUTIONS-IN-KENY.pdf

[43] Mohammed, S., Baburo, T.A.B., \& Karage, A.I. (2014). Assessing the impact of entrepreneurship education on students' job creation ability after graduation. European Journal of Business and Management, 5, 62-71.

[44] Musa, M.Y., \& Adewale, R.S. (2015). Effects of entrepreneurship education on willingness to own personal business among Nigerian university graduates. European Journal of Academic Research, 3, (1), 19-30. file://C:/Users/213574404/Downloads/MUSA\%20AND\% 20ADEWALE\%202015.pdf

[45] Mwasalwiba, E. S. (2010). Entrepreneurship education: a 
review of its objectives, teaching methods, and impact indicators. Education and Training. 52(1), 20 - 47. Available online: http://dx.doi.org/10.1108/004009110110 17663.

[46] Nabi, G. \& Linan, F. (2011). Graduate entrepreneurship in the developing world: intentions, education and development. Education + Training, 53 (5), 325-334.

[47] Obamuyi, T. M. \& Fapetu, O. (2016). The Nigerian economy in the face of socio-political challenges: a retrospective view and ways forward. Journal of Finance and Banking Studies 5(3), 32-41.

[48] Oduwole, T. A. (2015). Youth unemployment and poverty in Nigeria. International Journal of Sociology and Anthropology Research, 1(2), 23-39.

[49] Ojeifo, S.A. (2013). Entrepreneurship education in Nigeria: a panacea for youth unemployment. Journal of Education and Practice, 4 (6), 61 - 67.

[50] Potter, J. \& Halabisky, D. (2014). Supporting Youth in Entrepreneurship Summary report of a policy development seminar organised by the OECD and the European Commission, Brussels, 22nd-23rd September 2014.

[51] Piperopoulos, P. \& Dimov, D. (2015). "Burst bubbles or build steam? Entrepreneurship education, entrepreneurial self-efficacy, and entrepreneurial intentions,” Journal of Small Business Management, 53(4), 970-985.

[52] Salami, C.G.E. (2013). Youth unemployment in Nigeria: a time for creative intervention. International Journal of Business and Marketing Management. 1(2), 18-26.

[53] Silva, A., Henriques, E., \& Carvalho, A. (2009). Creativity enhancement in a product development course through entrepreneurship learning and intellectual property awareness. European Journal of Engineering Education, 34(1), 63-75.

[54] Saunders, M., Lewis, P., \& Thornhill, A. (2009). Research method for business students. $5^{\text {th }}$ Edition. England: Pearson.

[55] Sekaran, U. \& Bougie, R. (2016). Research methods of business: a skill-building approach. $7^{\text {th }}$ Edition, United Kingdom: John Willey \& Sons.

[56] Smith, A. M. \& Paton, R. A. (2011). Delivering enterprise: A collaborative International Approach to the development, implementation and assessment of entrepreneurship. International Journal of Entrepreneurial Behaviour and Research, 17(1), 104-118.

[57] Terjesen, S. (2017). Social entrepreneurship amongst women and men in the United State. Office of Advocacy, Small Business Administration: Special report.

[58] Thea, V.W. (2017). Theory U and individual entrepreneurial orientation in developing youth entrepreneurship in South Africa. Journal of Contemporary Management, 14, 531-553.

[59] Thompson, D., Poulston, J. \& Neil, L. (2017). How satisfying is real work? An analysis of student feedback on applied learning in hospital degree. Journal of Hospitality, Leisure, Sport and Tourism Education, 20,110-121.

[60] Uduak, M.E. \& Aniefiok, O.E. (2011). Entrepreneurship education and career intentions of tertiary education. International Education Studies, 4 (1), 172-178.

[61] Valerio, A., Parton, B. \& Robb, A. (2014). Entrepreneurship education and training programs around the world: dimensions for success. International Bank for Reconstruction and Development, World Bank. Available online: ttps://searchworks.stanford.edu/view/107 14019.

[62] Volkmann, C. Wilson, K.E., Vyakarnam, S., Sepulveda, A., Marriotti, S. \& Sepulveda, D (2009). Entrepreneurship in higher education in educating the next wave of entrepreneurs. A report of the global education initiative. Switzerland: World Economic Forum. Available online: WEF_EE_Full_Report.pdf.

[63] Wahid, A., Ibrahim, A. \& Hashim, N. B. (2016). The review of teaching and learning on entrepreneurship education in institution of higher learning. Journal on Technical and Vocational Education, 1(2), 82-88. file://C:/Users/213574404/Downloads/64-124-1-PB.pdf

[64] Welsh, D.H.B., Tullar, E.L. \& Nemati, H. (2016). Entrepreneurship education: Process, method, or both? 